Illinois State University

ISU ReD: Research and eData

Theses and Dissertations

9-6-2016

\title{
An Examination of How One University is Preparing Elementary and Middle Level Education Majors for Common Core Mathematics
}

Michelle Elizabeth Schwartze

Illinois State University, mschwartze17@gmail.com

Follow this and additional works at: https://ir.library.illinoisstate.edu/etd

Part of the Science and Mathematics Education Commons, and the Teacher Education and Professional Development Commons

\section{Recommended Citation}

Schwartze, Michelle Elizabeth, "An Examination of How One University is Preparing Elementary and Middle Level Education Majors for Common Core Mathematics" (2016). Theses and Dissertations. 634. https://ir.library.illinoisstate.edu/etd/634

This Dissertation is brought to you for free and open access by ISU ReD: Research and eData. It has been accepted for inclusion in Theses and Dissertations by an authorized administrator of ISU ReD: Research and eData. For more information, please contact ISUReD@ilstu.edu. 


\title{
AN EXAMINATION OF HOW ONE UNIVERSITY IS PREPARING \\ ELEMENTARY AND MIDDLE LEVEL EDUCATION \\ MAJORS FOR COMMON CORE MATHEMATICS
}

\author{
Michelle Schwartze
}

\section{Pages}

In 2010 the Common Core State Standards (CCSS) for mathematics and English Language Arts were introduced into K - 12 classrooms (Common Core State Standards Initiative, 2015b). The standards for mathematics focus on having students demonstrate and explain understanding more than the standards have in the past (Burns, 2013). McCallum (2011) divides the eight Standards for Mathematical Practice into four main themes: reasoning and explaining, modeling and using tools, seeing structure and generalizing, and overarching habits of mind of a productive mathematical thinker. These four themes encompass what a mathematics classroom should look like when utilizing the CCSS for mathematics. With this shift in the standards it creates a need for teachers to have a strong content knowledge and pedagogical understanding (Zhang, 2014). One place to look and see whether teachers are prepared for these new standards is the university level with teacher preparation programs. 
Methods courses have long been the place where preservice teachers gain pedagogical content knowledge (Shulman, 1987) and gain methods of teaching that can be carried into their own classrooms someday (Ball, 1990). This qualitative, phenomenological study examines how one large, midwestern university has addressed the CCSS for mathematics within their mathematics methods courses. Interviews, surveys, and document analysis were used to deeply explore one university's experiences with Common Core standards for mathematics. Data looked at how the professors were addressing the CCSS for mathematics within their methods courses as well as how the preservice teachers described their experiences with the CCSS for mathematics within these methods courses. Findings showed that the CCSS were mostly being addressed through classroom assignments as add-ons to created lesson plans. Student expectations and language were also being addressed within some of the methods courses.

KEYWORDS: Common Core, Elementary, Mathematics, Middle Level, Teacher Preparation 


\section{AN EXAMINATION OF HOW ONE UNIVERSITY IS PREPARING \\ ELEMENTARY AND MIDDLE LEVEL EDUCATION \\ MAJORS FOR COMMON CORE MATHEMATICS}

MICHELLE SCHWARTZE

A Dissertation Submitted in Partial

Fulfillment of the Requirements

for the Degree of

DOCTOR OF EDUCATION

School of Teaching and Learning

ILLINOIS STATE UNIVERSITY

2016 
(C) 2016 Michelle Schwartze 
AN EXAMINATION OF HOW ONE UNIVERSITY IS PREPARING

ELEMENTARY AND MIDDLE LEVEL EDUCATION

MAJORS FOR COMMON CORE MATHEMATICS

MICHELLE SCHWARTZE

COMMITTEE MEMBERS:

Douglas Hatch, Chair

Ellis Hurd

Jay Percell 


\section{ACKNOWLEDGMENTS}

First and foremost I would like to thank my dissertation chair, Dr. Douglas Hatch, for his support and guidance along my journey. When I told him that I wanted to be done with my dissertation in a year he did not tell me it was impossible, instead he said while it would be difficult, he believed that I could do it. Thanks for that belief in me. Thanks also for your hours of editing my rough drafts and all of the constructive criticism you provided. Dr. Hatch also believed in me enough to help me get my first publication in a journal and my first podcast interview. I will be forever grateful for those experiences!

I also want to thank my other committee members, Dr. Ellis Hurd and Dr. Jay Percell, for also giving me support and guidance in my journey. When I spoke with Dr. Hurd about my dissertation plans he also said my timeline may be difficult but that he knew I was a hard worker and believed I could do it. That meant a lot to me! I appreciate your time proofreading my rough drafts as you always caught my simple mistakes and provided many ideas of pathways I could take my writing.

Dr. Percell was first a peer of mine as we began our doctoral journey at the same time, and then became my dissertation chair. He has helped me to stay focused on my methodology and provided many resources to guide my writing. Thank you for being patient with me in my journey through phenomenology and for teaching me along the way. 
This committee has been so supportive and helpful in my dissertation journey. I could not have gotten where I am today without this wonderful committee to lead the way, so thanks for that!

I also wish to thank all of my professors that I have encountered in my time at the School of Teaching and Learning at Illinois State University. I have learned so much in my courses about education, research, and teaching. Not only have I learned from the professors, but I have also learned a lot from fellow doctoral students that I have shared classes with. Many of them still support me as I complete my dissertation and further on my research in education and that support has helped me to persevere in times of frustration or fatigue.

My family has been the biggest part of who I am today and so I definitely must thank them. As a young child I watched my father graduate with his master's degree and from that moment on I realized that learning is lifelong. My parents have always instilled in me the values of hard work and persistence. They have believed in me and always made me feel like I could do anything if I set my mind to it. Thank you Mom and Dad for your guidance and love!

I also want to thank my older sister, Heather, who was the first in our family to get a doctorate. She has always been my smarter, older sister who I looked up to, admired, and wanted to imitate. In all honesty, her getting her doctorate pushed me to pursue mine and so I thank her for building that fire within me to further my learning. My younger sister, Christi, also deserves thanks as she has helped instill in me a competitive fire. She has always been the most competitive in our family and that drives 
me to compete a little bit more. That competitiveness has helped me to get where I am today.

While my children, Emma and Keegan, are still young I know they have seen my journey through my many nights at class or when I have had to lock myself up in my room to study. I also know they will be happy to have mommy back again, and I am happy to be able to give them the presence that I have been unable to while working on this degree. They are my heart and I love them to infinity and beyond!

Ultimately, none of this would have even been possible without the love and support of my husband, Aaron. He has supported me through my master's degree and now my doctorate. During those times when I would be frustrated and wanting to quit this journey, he was there telling me that I could do it. He spent numerous nights watching our children while I was at class or studying. Your support has pushed me to become a better person and I only hope that I give you that same love and support that you have shown me. There is no one else that I could imagine sharing my life with. Thank you for sharing life's journey with me - I love you! 


\section{CONTENTS}

\section{Page}

ACKNOWLEDGMENTS

CONTENTS

TABLES

viii

FIGURES

ix

\section{CHAPTER}

I. INTRODUCTION

Introduction to Topic

Research Purpose

Conceptual Framework

Brief Literature Review

Common Core Standards for Mathematics 6 Math Methods Courses $\quad 7$

The Implementation of Common Core into Math Methods 8

$\begin{array}{lr}\text { Research Questions } & 9\end{array}$

Research Methodology $\quad 9$

Definition of Key Terms 10

Research Site and Participants 11

Data Analysis $\quad 13$

Significance of Research 13

II. REVIEW OF SELECTED LITERATURE 15

Historical Context of Mathematics Education $\quad 15$

$\begin{array}{ll}\text { Common Core Standards for Mathematics } & 16\end{array}$

Positive Impacts of Common Core Mathematics 17

Issues/Concerns with Common Core Mathematics 18 
$\begin{array}{ll}\text { Preservice Teacher Preparation } & 20\end{array}$

Positive Impacts of Math Methods Courses $\quad 21$

Issues/Concerns with Math Methods Courses 22

Integration of Common Core Math Standards into Math 24 Methods Courses

Familiarity with Standards 25

Changes to Higher Education $\quad 26$

The Future of Common Core Mathematics 27

Collaboration with Educators $\quad 27$

Content Within the Standards 28

Is Teacher Preparation Changing? 29

Conclusion $\quad 30$

III. METHODOLOGY 32

Research Questions $\quad 32$

Research Paradigm 33

Type of Study $\quad 34$

Data Collection and Analysis 35

$\begin{array}{ll}\text { Research Setting } & 37\end{array}$

Sampling Strategies $\quad 38$

Instruments for Data Collection 39

$\begin{array}{ll}\text { Ethical Issues } & 41\end{array}$

Positionality $\quad 41$

Reflexivity $\quad 42$

Trustworthiness and Reliability 44

Significance of Study $\quad 45$

$\begin{array}{ll}\text { Conclusion } & 46\end{array}$

$\begin{array}{lll}\text { IV. FINDINGS } & 47\end{array}$

Description of Sample $\quad 47$

Findings $\quad 48$ 
Research Question 1: In What Ways do University Professors Address CCSS for Mathematics in Their Math Methods Courses?

Classroom assignments

Preservice teacher expectations $\quad 55$

Language

Summary of Results from Research Question 1

Research Question 2: How do Elementary and Middle Level Majors Describe Their Experiences with CCSS in Their Math Methods Courses?

Classroom assignments

Summary of Results from Research Question 2 67

Summary of Documentation $\quad 68$

Findings Linked to Conceptual Framework 69

Reasoning and Explaining $\quad 70$

Modeling and Using Tools $\quad 71$

Seeing Structure and Generalizing $\quad 72$

Overarching Habits of Mind of a Productive Mathematical

Thinker

Trustworthiness $\quad 74$

The Role of the Conceptual Framework 75

$\begin{array}{ll}\text { Summary } & 76\end{array}$

$\begin{array}{lll}\text { V. SUMMARY AND CONCLUSIONS } & 78\end{array}$

$\begin{array}{ll}\text { Introduction } & 78\end{array}$

Summary of Results $\quad 79$

Conclusions $\quad 82$

Focus on Lesson Plans $\quad 82$

Varied Teacher Agendas $\quad 84$

Practices Not Always Emphasized 86

Implications of Addressing CCSS in Methods Courses 88

Implications for University Professors $\quad 88$ 
Implications for Preservice Teachers $\quad 89$

Implications for the Community 90

Limitations $\quad 90$

Future Research $\quad 91$

$\begin{array}{ll}\text { Conclusion } & 92\end{array}$

$\begin{array}{ll}\text { REFERENCES } & 94\end{array}$

APPENDIX A: Faculty Recruitment Letter 106

APPENDIX B: Telephone Script for Faculty Recruitment 108

APPENDIX C: Interview Questions for Faculty 109

APPENDIX D: Recruitment Letter for Preservice Teachers 111

APPENDIX E: Online Survey for Preteacher Candidates 112

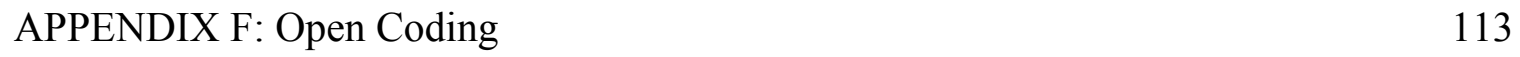




\section{TABLES}

Table $\quad$ Page

1. Data Collected from University Professors 37

2. Pseudonyms for Sample of University Professors 39 


\section{FIGURES}

Figure

Page

1. Grouping for the Common Core Standards for Mathematical Practice 


\section{CHAPTER I}

\section{INTRODUCTION}

In the nineteenth century, education began to focus more on a child-centered philosophy that revolved around the ideas of progressive education (Reese, 2013). John Dewey in the early 1900s was one of the founding theorists on the ideas behind progressive education and he believed that children needed their learning to be connected to their personal experiences (Ellis \& Berry III, 2005). Skemp (1976) went further and argued that mathematics should not only be taught as a set of rules, but in ways that ensured students understood what they were doing mathematically. This new way of thinking moved away from memorization and more towards understanding, which was a difficult adjustment for educators who were so familiar with teaching memorization from a textbook (Reese, 2001). Reese (2001) explains, "Real schools and ordinary teachers valued the traditional curriculum, books, and old-fashioned pedagogy. That was how most teachers had been taught" (p. 21).

\section{Introduction to Topic}

Mathematics education in the United States has changed throughout the years leading to what some call "math wars" (Klein, 2007; Schoenfeld, 2004). This fight regarding the best way to learn mathematics hugely impacted education in 1989 when the National Council of Teachers of Mathematics (NCTM) published a new set of standards for mathematics. This new set of standards asked that students become problem solvers, 
communicate what they are doing mathematically, and become confident mathematicians (Schoenfeld, 2004). After releasing these standards, NCTM went further in publishing Principles and Standards for School Mathematics (2000). These standards reinforced progressive ideals from the 1920s of discovery learning (Klein, 2003). Students were now more than ever having to show understanding of mathematics concepts and explain their reasoning (NCTM, 2000).

To help implement the NCTM standards there was support from the National Science Foundation (NSF). The NSF supported the development of new mathematics curricula that was aligned with the NCTM standards (Klein, 2003). This new curricula was introduced into $\mathrm{K}-12$ schools around the United States. One issue with the new curricula was that the textbooks were lacking examples and some topics were missing or being repeated too often (Klein, 2003). Parents and educators fought back against this new mathematics curricula, which created more "math wars" in education (Klein, 2003; Klein, 2007).

In 2010, a new set of standards for language arts and mathematics was introduced that were meant to be rigorous and "ensure all students, regardless of where they live, are are graduating high school prepared for college, career, and life" (Common Core State Standards Initiative, 2016, para. 1). With the introduction of the Common Core State Standards (CCSS) there has been another shift towards demonstrating understanding in mathematics (Burns, 2013; VanTassel-Baska, 2015). Within the CCSS for mathematics you can see the notion of understanding by looking at the standards for mathematical practice: make sense of problems and persevere in solving them, reason abstractly and quantitatively, construct viable arguments and critique the reasoning of others, model 
with mathematics, use appropriate tools strategically, attend to precision, look for and make use of structure, and look for and express regularity in repeated reasoning (Common Core State Standards Initiative, 2015a). These standards are very similar to the NCTM Principles and Standards for School Mathematics (2000) as those were used as a guideline in creating the CCSS for mathematics. Students are once again asked to make sense of the problems they are solving and communicate understanding of the mathematics concepts they are learning. Burns (2013) explains it as“...students should be able not only to figure out the answer to a problem like $15 \times 12$, but also to demonstrate an understanding of multiplication as defined by the practice standards" (p. 44).

Preservice teachers need to be prepared to deeply understand the mathematics concepts they will be teaching (Ma, 1999; Schmidt, 2015). The 'math wars' we are seeing today are again leading towards this idea of understanding mathematics, and teachers in the classroom are the ones that will be expected to pass that understanding on to students. As Reese (2001) explained, teachers tend to teach others the same way that they were taught. If preservice teachers are taught understanding in mathematics then they may be more likely to pass those methods on to their own students.

Although the CCSS seem to mostly be impacting schools serving kindergarten through high school age students, colleges are also being impacted as they prepare preservice teachers to teach mathematics following these standards. Since the CCSS are changing curriculum within the high schools, the incoming students are entering college with different backgrounds of knowledge (Jones \& King, 2012). It is important that schools are talking with universities and aligning curriculum in order to best prepare preservice teachers for what they will be teaching within their own classrooms someday. 
Math methods courses have been shown to improve preservice teachers' attitudes towards mathematics (Quinn, 1997; Wilkins \& Brand, 2004). Those attitudes could be helpful to teachers in the classroom because they can pass those positive attitudes on to their students. The mathematical content knowledge in preservice teachers also needs to be strong so they will be able to confidently teach the content to others. The content that is taught within the methods courses should match the content that preservice teachers will find within the classrooms they will be teaching (Zhang, 2014).

\section{Research Purpose}

The purpose of this study is to determine the degree to which a large, midwestern university is incorporating Common Core standards within their math methods courses. Since the Common Core standards for mathematics were introduced into $\mathrm{K}-12$ classrooms it would be imperative to understand whether or not institutions of higher education are adapting their teacher preparation curricula to fit the CCSS for mathematics.

The CCSS for mathematics are introducing more rigorous standards for all children and thus teachers must be prepared with strong pedagogical knowledge (Association of Public and Land-Grant Universities, 2011). This raises the question, are universities taking these more rigorous standards into consideration within their math methods courses? This study explores one university's math methods courses and how they have addressed the standards within their curriculum. While the purpose of this study is not to generalize the results to other universities, the information obtained from this exploratory phenomenological qualitative study could be helpful in gaining 
understanding of one major teacher education university's purposes for preparing candidates' understandings of the CCSS for mathematics.

\section{Conceptual Framework}

This study is an inquiry to see how Common Core State Standards (CCSS) for mathematics are being implemented within math methods courses in a teacher education program. Within the CCSS for mathematics, a variety of math skills and concepts are included. For the purpose of this study a specific skill or concept will not be the focus, but rather in general how the CCSS have been implemented. Since a specific skill or concept is not the focus of this research, the standards for mathematical practice will be the conceptual framework.

The standards for mathematical practice describe how students in a mathematics classroom should be practicing mathematics through the CCSS. There are eight standards: make sense of problems and persevere in solving them, reason abstractly and quantitatively, construct viable arguments and critique the reasoning of others, model with mathematics, use appropriate tools strategically, attend to precision, look for and make use of structure, and look for and express regularity in repeated reasoning (Common Core State Standards initiative, 2015a). These standards for mathematical practice provide teachers with methods for students to learn the math concepts within the standards (Common Core State Standards initiative, 2015a). 


\section{Reasoning and Explaining}

- \#2: Reason abstractly and quantitatively

- \#3: Construct viable arguments and critique the reasoning of others

\section{Modeling and Using Tools}

- \#4: Model with mathematics

- \#5: Use appropriate tools strategically

\section{Seeing Structure and Generalizing}

- \#7: Look for and make use of structure

- \#8: Look for and express regularity in repeated reasoning

\section{Overarching habits of mind of a Productive Mathematical Thinker}

-\#1: Make sense of problems and persevere in solving them

- \#6: Attend to precision

Figure 1. Grouping for the Common Core Standards for Mathematical Practice.

McCallum (2011) developed a way to group mathematical standards into four parts: reasoning and explaining, modeling and using tools, seeing structure and generalizing, and overarching habits of mind. This way of grouping the standards can be seen in Figure 1. For this study the researcher looked at how a large, midwestern university is incorporating these groups of mathematical standards into their mathematics methods courses.

\section{Brief Literature Review}

\section{Common Core Standards for Mathematics}

The CCSS introduced a set of content standards for mathematics along with a set of standards for mathematical practice. The standards for mathematical practice describe what a mathematics classroom would look like if the CCSS for mathematics content standards were being implemented. In such a classroom the students would be 
persevering on problem solving, modeling mathematics, and constructing arguments in regards to the mathematical answers they are getting.

When the CCSS entered classrooms in 2010 they were meant to be guidelines for teachers to follow when building their own curricula (Eilers \& D'Amico, 2012). The standards for mathematical practice can be used to guide teachers in building their classroom learning. The focus in the CCSS for mathematics is on explaining mathematical thinking and reasoning through the mathematics instead of just memorizing a rule. With the standards for mathematical practice "students should be able not only to figure out the answer to a problem like $15 \times 12$, but also to demonstrate an understanding of multiplication as defined by the practice standards" (Burns, 2013, p. 44).

This change in student learning is not just coming up in kindergarten through $12^{\text {th }}$ grade classrooms, but also in higher education among preservice teachers that need to be prepared for teaching these standards (Sawchuk, 2012). With a more rigorous curriculum that focuses on understanding the mathematics concepts, preservice teachers will need to be sure they are prepared thoroughly with content knowledge (Zhang, 2014). Some argue that $\mathrm{K}-12$ schools are not prepared to teach these higher-level skills (VanTassel-Baska, 2015), but with appropriate preparation teachers should be able to address CCSS for mathematics within their classrooms.

\section{Math Methods Courses}

Methods courses in education are usually meant to address pedagogical content knowledge and curricular knowledge (Graeber, 1999). Shulman (1987) defines pedagogical content knowledge as combining content knowledge and pedagogy in a way that allows one to present knowledge to students in manners that fit their educational 
needs. Methods courses have been shown to improve preservice teachers' attitudes towards mathematics (Quinn, 1997; Smith, Swars, Smith, Hart, \& Haardorfer, 2012; Wilkins \& Brand, 2004). One problem within math methods courses is that there is a lack of consistency among institutions of higher learning in regards to how they teach these methods courses. The requirements for elementary education candidates vary dramatically from school to school. In a study of 33 education schools, Greenberg and Walsh (2008) found that four of them had no math methods coursework and 12 of the schools had programs that combined elementary and middle school level math methods. Without consistency it could be hard to ensure that teachers are well prepared to teach mathematics when they graduate.

\section{The Implementation of Common Core into Math Methods}

Math methods courses often address the understanding behind why certain methods work in mathematics (Graeber, 1999). In the CCSS for mathematics this idea of representation and understanding is also present within the standards for mathematical practice (Burns, 2013; Common Core State Standards initiative, 2015a). Even with this correlation between methods courses and the CCSS, Weiss (2015) has found fewer than a third of all elementary education training programs are adequately preparing students for the CCSS. This research specifically looks at math methods courses for elementary education and middle level education majors at a large, midwestern university to see how they are addressing the CCSS for mathematical practice within their courses. 


\section{Research Questions}

As such, the research questions that were explored are:

1. In what ways do professors at a large, midwestern university address Common Core standards for mathematics in their elementary and middle level math methods courses?

2. How do elementary education and middle level education majors at a large, midwestern university describe their experiences with Common Core standards in their math methods courses?

Through the analysis of data obtained in response to these two research questions, the researcher determined the degree to which preservice teachers at this university are being prepared to teach mathematics using Common Core standards for mathematical practice.

\section{Research Methodology}

The research design is qualitative, and a phenomenological approach was used. In phenomenological research a specific phenomenon is being explored (Creswell, 2013). A North American view of phenomenology was addressed within this research since this study seeks to make sense of peoples' personal experiences (Denscombe, 2003). In this research the phenomenon examined was the Common Core standards for mathematics and how they are being used in mathematics methods courses to prepare preservice teachers. The culture, or set of shared values and beliefs (Hudelson, 2004), explored was that of preservice teachers in elementary education and middle level education mathematics methods courses and their professors. Since the culture being examined throughout this study was believed to be part of the research process as well, a 
phenomenological approach was supported (Hatch, 2002). For this research the culture's ideas, beliefs, and attitudes towards the implementation of CCSS within their mathematics methods courses was explored.

\section{Definition of Key Terms}

For the purpose of this study, the following definitions were used:

- Common Core State Standards (CCSS) for mathematics: When addressing the CCSS within this paper they will refer to the set of learning goals entering $\mathrm{K}-12$ classrooms around the United States in 2010 (Common Core State Standards initiative, 2015b; Center for Public Education, 2014). The standards express what students should be learning at each grade level from kindergarten through twelfth grade in their mathematics classrooms (Common Core State Standards initiative, 2015b).

- The Standards for Mathematical Practice: Developed from the CCSS, the Standards for Mathematical Practice focus on the processes of mathematical learning (Common Core State Standards initiative, 2015a). These standards are specific to mathematics and deal more with how students should be practicing the standards in the classroom.

- Math methods courses: For this study an elementary level math methods course and a middle school math methods course were explored. Both of those methods courses have a focus on planning instruction of mathematics for students. The math methods courses used in this research also implemented a clinical aspect to the course where students taught small groups of students in a school setting, allowing them to implement 
their planned instruction. The researcher will define math methods courses for this research as ones that focus on math topics as well as pedagogical content knowledge to help with planning and implementing instruction (Shulman, 1987).

- Pedagogical Content Knowledge: Shulman (1987) defines pedagogical content knowledge as “...the blending of content and pedagogy into an understanding of how particular topics, problems, or issues are organized, represented, and adapted to the diverse interests and abilities of learners, and presented for instruction" (p. 8). This definition will be used when discussing pedagogical content knowledge within this study.

- Rigor: Throughout this study the term rigor is used to define academics. The definition of rigor that the researcher is using is described by Blackburn (2012) as an environment of learning in which students have high expectations and can demonstrate their learning through increased student engagement in the classroom. The third component of Blackburn's definition is that students are given support in the classroom to be able to reach those higher levels of learning.

- Preservice teacher: In this study the preservice teachers are those students participating in an elementary or middle level education program with the intent of becoming educators.

\section{Research Site and Participants}

The participants for this study were elementary and middle level education majors in the teacher preparation program and professors of elementary and middle level math 
methods courses. One course examined was math methods for elementary level preservice teachers (Kindergarten through $8^{\text {th }}$ grade) and the other one focused on middle level preservice teachers $\left(6^{\text {th }}\right.$ grade through $8^{\text {th }}$ grade). The current elementary license for the state where this research will take place is for students in Kindergarten through $9^{\text {th }}$ grade, but that licensure is expected to change soon and elementary will consist of Kindergarten through fifth grade while middle level will be sixth through eighth. With the licensure changing the courses have slightly been impacted as middle level preservice teachers no longer just need an endorsement but rather will focus their coursework solely on teaching the middle grades. When this research began the licensure was Kindergarten through ninth and thus, for the point of this research, data from both the both elementary and middle level math methods courses will be examined.

Sampling was done at the same large, midwestern university where this qualitative study into Common Core mathematics implementation was taking place. Preservice teachers enrolled in these math methods courses when this research took place, along with the professors teaching the courses, were the sample used. For this reason the sample is purposive in order to ensure that the research question is being specifically examined (Denscombe, 2003).

In this study preservice teachers who were currently enrolled in an elementary or middle level math methods course were offered an opportunity to participate in the study via email. If they chose to participate they completed an online survey asking them about their experiences with Common Core standards in their current math methods course. The professors for the math methods courses were interviewed using open-ended 
questions regarding the ways that they address Common Core standards for mathematics in their math methods courses.

Artifacts from the classes, such as assignments or syllabi outlining the class goals, were also collected. These artifacts, along with the survey and interview data, were analyzed in order to gain better insight into how the university is preparing elementary and middle level education majors for Common Core mathematics.

\section{Data Analysis}

After the student surveys were completed the responses were grouped according to question. The faculty interviews were recorded and transcribed. The researcher first used open coding for the transcriptions and survey results in order to separate similar concepts. These concepts were noted by highlighting related topics in similar colors (Biddix, 2009). In order to examine these similarities and differences more thoroughly a construct table was then used to record key concepts from the surveys and interviews (Miles, Huberman, \& Saldaña, 2014). Documents such as class projects or syllabi were then included with the data to see how they relate with the concepts found in the surveys and interviews. Descriptive coding was used for the documents in order to make it easier to classify them among the previous found concepts (Saldaña, 2009). For this phenomenological research, triangulation with the faculty interviews, preservice teacher surveys, and course documents was used to compare individual interpretations (Lodico, Spaulding, \&Voegtle, 2010).

\section{Significance of Research}

Common Core is still fairly new for educators, students, and parents since its adoption into the classrooms in 2010 (Center for Public Education, 2014). There has been 
some controversy over this new set of standards, but the reality is that many states have adopted these standards and preservice teachers need to be prepared to teach them in the classroom (Kober \& Rentner, 2011; Porter, McMaken, Hwang, \& Yang, 2011). In order to ensure that preservice teachers are ready for this challenge, universities need to make sure they are addressing the Common Core in their curriculum (WICHE, 2011).

The Common Core standards for mathematics prepare students to demonstrate their understandings more than they did in the past, which requires that teachers have a deep content knowledge (WICHE, 2011). Since this way of learning mathematics is new to many it is important that higher education institutions assess their current math methods courses to prepare preservice teachers adequately. This examination only looks at one large, midwestern university and its implementation of Common Core standards into the math methods courses, but this information could serve to lead other universities to examine their own programs for math education and it might serve as an incentive for the university in the study to examine their own course offerings. 


\section{CHAPTER II}

\section{REVIEW OF SELECTED LITERATURE}

Within this study, elementary and middle level math methods courses at a university were explored to determine the degree to which Common Core State Standards (CCSS) are being addressed within the curriculum. This chapter will examine current research and existing theories regarding student learning, Common Core standards, and mathematics curriculum.

\section{Historical Context of Mathematics Education}

Mathematics education has seen many changes throughout the years. In 1965 the Federal government began to take more control over education with the Elementary and Secondary Education Act (ESEA), which later became No Child Left Behind (NCLB) in 2001. In 1983 with $A$ Nation at Risk we began to see big changes to curriculum in education as the Standards-Based Education Reform movement took over (Pae, Freeman, $\&$ Wash, 2014). In an effort to increase academic performance in mathematics and science the curriculum became more rigorous. In 1989 the National Council of Teachers of Mathematics introduced a set of standards meant to support ideas in A Nation at Risk (Klein, 2003). These standards introduced a way of teaching that asked students to understand concepts and not just procedures. These changes to curriculum are still taking place with the introduction of the CCSS into classrooms in 2010. 
With all the changes in mathematics curricula taking place in education, a question to consider would be whether preservice teachers are being adequately prepared to implement the CCSS for mathematics into their teaching. Research describing the CCSS for mathematics in detail will be shared followed by research that explores how preservice teachers are being prepared for mathematics education, and finally the literature search will examine how CCSS are being incorporated in math methods courses.

\section{Common Core Standards for Mathematics}

The CCSS Initiative began in 2009 when the National Governors Association and the Council of Chief State School Officers developed a set of standards for English Language Arts (ELA) and mathematics (Rust, 2012). In 2010 these standards were sent out to schools and implementation was to begin in the 2011 to 2012 school year for most schools.

The purpose of these standards was to help ensure students were prepared for success either in college or another career path (Rust, 2012). The National Governors Association (NGA) and the Council Chief State School Officers (CCSSO) developed these standards with feedback from teachers, parents, and school administrators (Common Core State Standards Initiative, 2015b). In a study conducted by Kober and Rentner (2012) they found that 30 of the states that have adopted CCSS felt as though the new standards were more rigorous than the standards they had previously. The feeling that the mathematics standards are more rigorous could come from the Common Core standards having a focus on not just the procedures, but also the conceptual understanding (Burns, 2013; Common Core State Standards Initiative, 2015b). 
Blosveren, Liben, and DeWitt (2014) identify three areas where there have been changes to mathematics with the implementation of the CCSS. The first is a sharper focus on fewer key topics. By focusing on a smaller list of main concepts it could allow the teacher more time to deeply develop understanding of that content. The second area of change is in a more coherent progression of skills and concepts. In mathematics, the content builds with the concepts staying the same but the depth changing (Tooke, 1997). In the CCSS this progression can be seen across grade levels. The final area of change addressed by Blosveren, Liben, and DeWitt is in the rigor of the mathematics being addressed. The CCSS asks students to solve and explain real-world problems by applying mathematical concepts.

\section{Positive Impacts of Common Core Mathematics}

The purpose of having common standards in the United States was to provide all students with a high quality education (Common Core State Standards Initiative, 2015b). The standards are also geared towards student success in college and their future careers (Bomer \& Maloch, 2011; Rust, 2012). This would provide students with tools to be successful in their careers.

Overall, the standards appear to be met with positivity as Kober and Rentner (2012) found that only three states out of the 46 (including D.C.) that had adopted the CCSS at the time of this survey said they would consider changing their decisions. Cogan, Schmidt, and Houang (2013) also found that parents seem to be mostly positive regarding the CCSS as $68 \%$ of parents they surveyed supported common standards for mathematics. 
The new mathematics standards have been more rigorous by focusing on not only the mathematical procedures, but on conceptual understandings of the mathematics (Dunkle, 2012). This rigorousness is seen by the stronger emphasis on reasoning, connections, and active learning that can be seen in the CCSS for mathematics and the Standards for Mathematical Practice (Common Core State Standards initiative, 2015a; Gojak, 2013). No longer is mathematics about memorizing a rule, but now students are being asked to explain what they are doing and why it works that way. Schmidt (2015) describes Common Core mathematics as encouraging "students to think deeper and to think critically" (para. 5). The CCSS for mathematics provide more time to focus on understanding mathematics.

\section{Issues/Concerns with Common Core Mathematics}

With the CCSS for mathematics presenting more rigorous material, teachers need to make sure they are prepared more with content knowledge (Schmidt, 2015; Zhang, 2014). Part of being prepared is having resources available to help support teaching. That is one area that is challenging, as many school districts do not have the money to purchase new materials. If a teacher does not have curriculum resources available then he or she is less likely to implement CCSS (Zhang, 2014).

Teachers oftentimes lack extra time to create their own resources, so having those available would help teachers be more likely to use CCSS in their classrooms. Making those available would require money from the school or district. Cost, though, is one major issue with the implementation of the CCSS and this has caused some states to struggle with implementation (McGuinn, 2015). In a study of 33 schools that have implemented CCSS, Kober and Rentner (2012) found that 30 of the states felt the 
implementation of Common Core would require new or revised curriculum materials for mathematics. Finding resources that fit into a school's budget are one big challenge with this need for new curriculum materials.

Not only do school's need to find resources, but they need to find quality resources that are aligned well with the standards. In a 2012 online survey by the Editorial Projects in Education (EPE) Research Center (2013), they found that only 44\% of teacher respondents felt their textbooks were aligned to the CCSS. Another online survey from the 2013 - 2014 school year (Education Week Research Center, 2014) found only $41 \%$ of teachers believed their textbooks were aligned to the CCSS. With the emergence of new standards teachers already have a tough job of figuring out the best methods for implementing these standards into the curriculum, and that job is made even harder when the materials they are given to work with are not already aligned to those standards.

At the state level a challenge emerging with the CCSS is developing teacher evaluation systems to hold teachers accountable for student mastery of the standards (Zhang, 2014). Many states are not getting guidance on how to create teacher evaluation systems that align with CCSS. Kober and Rentner (2011) found that almost two thirds of the districts that have implemented CCSS felt that lack of clear guidance from their state education agencies was a challenge to their implementation process.

Another challenge with the teacher evaluation systems is that they have not had time to catch up with the newness of CCSS. At the same time that the CCSS were introduced, around 40 states adopted laws that linked their teacher evaluations to student performances on standardized testing (Fairbanks, 2015). The standardized tests being 
used now are new and fit a tougher set of standards than our students are used to seeing. Pimentel (as cited in Fairbanks, 2015) claims, "We need to unhook assessments from teacher evaluations for a while. Teachers need time and support to acquaint themselves with the new standards before high-stakes consequences are applied" (Two Separate Conversations section, para. 12).

There also seems to be a communication gap somewhere between educators and parents in regards to the CCSS. In the annual PDK/Gallup Poll it was found that only $23 \%$ of public school parents had learned about CCSS from teachers or other educators. Thirty-eight percent of them, though, had learned about CCSS from the media. This has led to some mixed views of Common Core mathematics by some parents (Foster, 2014).

While some parents are having concerns with the CCSS, many teachers are also struggling with the implementation. Some teachers find that their lack of pedagogical content knowledge is a challenge when it comes to implementing CCSS (Zhang, 2014). This challenge, along with the others mentioned above, may be part of the reason why teacher support of the CCSS is decreasing. In 2013, 76\% of teachers supported the Common Core, while in 2015 that support was only shown by $40 \%$ of teachers (DeNisco, 2016). Teachers need to be prepared to teach this new set of standards and feel comfortable enough with the material so they can help students be successful. Feeling more familiar with the standards may also help increase teacher support of these standards.

\section{Preservice Teacher Preparation}

With the recent emergence of the CCSS there is a dearth of research into the implementation of CCSS mathematics into teacher preparation programs. The National 
Council on Teacher Quality (NCTQ) did a study examining teacher preparation in 2013 and found that many elementary mathematics programs were not able to adequately cover math content because of a lack of time to cover all the material (Greenberg, McKee \& Walsh, 2013). Content cannot be limited with the new standards since they are more rigorous and thus require that students have even more content knowledge in mathematics (Sawchuck, 2012).

These standards are asking our students to engage at a deeper level with mathematics; but to do that they will need teachers that have strong understanding of mathematical concepts and are able to guide students to deeper understandings (Schmidt, 2015). While content is usually addressed within a mathematics content course, the focus in a mathematics methods course is often on pedagogy and how preservice teachers can apply mathematics activities within their classrooms to help their students learn (Ball, 1990; Burton, Daane, \& Giesen, 2008). Mathematics methods courses are one place where pedagogical content knowledge can be addressed with preservice teachers.

\section{Positive Impacts of Math Methods Courses}

Ingersoll, Merrill, and May (2012) examined teacher retention among math and science teachers and found that those teachers who had taken more courses in teaching methods and strategies were significantly less likely to leave the profession. The data source that they examined was the National Center for Education Statistics' 2003 - 2004 Schools and Staffing Survey and the $2004-2005$ Teacher Follow-Up Survey. These data were collected before the introduction of CCSS, so one thing that needs to be considered now is how this shift in standards may have increased the need for instruction of these 
methods and strategies as they require teachers now to focus not just on content but on process (Dunkle, 2012).

Smith et al. (2012) looked at a sample of 276 elementary preservice teachers and how the number of math content courses and math methods courses impacted their mathematical pedagogical beliefs, teaching efficacy beliefs, and content knowledge for teaching. One group took three math content courses and two math methods courses while the other group completed four math content courses and one methods course. A significant difference was not found between the groups implying that content knowledge did not change depending on how many content or methods courses were taken. What they did find, though, was that students with a higher specialized content knowledge did have greater teacher efficacy. This shows how important it is that teachers have strong content knowledge so they can feel more confident in their teaching. Math content courses and math methods courses both provide students with a stronger content knowledge that will help them with their efficacy and pedagogical beliefs as well.

\section{Issues/Concerns with Math Methods Courses}

One main issue with mathematics education is that there is no consistency. Greenberg and Walsh (2008) studied the mathematics education of elementary teachers in 77 education schools throughout the United States. What they found was that the requirements for elementary education candidates varied from zero to six mathematics courses required. Without consistency it is hard to ensure that quality teachers are being prepared. This lack of consistency could also be attributed to a difference in philosophies between math departments and teacher preparation departments, which is oftentimes the case (Smith et al., 2012). 
One specific area of weakness that Greenberg and Walsh (2008) found was in algebra instruction. They found that 52 percent of the schools they surveyed provided less than 15 percent of class time to algebra. This study was done before the implementation of the CCSS, so it would be interesting to see if that statistic has changed since algebra is a large focus of the mathematics standards for Common Core. Algebra can be seen in the Common Core standards beginning in Kindergarten through the title "Operations \& Algebraic Thinking” (Common Core State Standards initiative, 2015c).

Understanding of concepts in upper elementary grades is important for preservice teachers, but not always addressed within math methods courses. Burton, Daane, and Giesen (2008) looked more deeply into this idea by comparing two groups of preservice teachers taking math methods courses. The experimental group received 20 minutes of instruction each time they met on fifth- and sixth-grade mathematical content while the control group worked on pedagogical activities the entire time. The Content Knowledge for Teaching Mathematics Measure (CKT-M) developed by Hill, Schilling, and Ball (2004) was used as a pre- and posttest. Results showed that the control group scored higher than the experimental group on the pretest, but lower on the posttest. The extra 20 minutes of instruction that was given to the experimental group in middle grades content knowledge seemed to be effective in helping to increase their content knowledge for teaching mathematics. Possibly one area of concern in mathematics methods courses that could be addressed is lack of content knowledge being addressed as this study has shown the importance of such instruction.

Schmidt (2012) looked at elementary and middle level teachers in the classroom to see their confidence in regards to mathematics topics. He found that when middle 
school teachers were shown a list of advanced mathematics topics that at least three fourths of them stated they were well prepared to teach zero of the topics presented. Elementary teachers also showed a lack of confidence in advanced math topics. This is concerning since the CCSS are asking mathematics teachers to address more rigorous mathematics content (Dunkle, 2012; Schmidt, 2012).

One reason why Schmidt (2012) felt there was a lower confidence in elementary and middle level teachers in regards to mathematics is due to the lack of consistency in training of Kindergarten to eighth grade teachers. He goes on to say, "There is considerable variation in the proportion of elementary school teachers that have majors or minor in mathematics, ranging from almost none in the first grade to $65 \%$ in Grade 8 " (Schmidt, 2012, p.145). This implies that the lack of content knowledge may be related to teacher preparation.

\section{Integration of Common Core Math Standards into Math Methods Courses}

In 2010 the CCSS for mathematics were introduced within classrooms around the United States (Common Core State Standards initiative, 2015b). In-service teachers were thrown into these new standards with sometimes very little guidance. Preservice teachers, on the other hand, have an opportunity to be prepared for these standards before entering the profession. In a pilot project done by the Council of Chief State School Officers they found very few teacher preparation programs were incorporating Common Core standards into their curriculum (Weiss, 2015). Catherine Gewertz (as cited in Weiss, 2015) says, "What we often hear is that they feel it's not their job to prepare teachers for a specific set of standards" (p.29). Whether it is the job of the university or not, a math methods course could be a place to incorporate these standards of learning so that 
preservice teachers are not thrown into a classroom with little guidance as to what they are teaching. With the implementation of CCSS, universities will need to examine how they will fit the standards among the content in a way that prepares teachers for the classroom.

\section{Familiarity with Standards}

Pae, Freeman, and Wash (2014) suggest that teacher preparation programs prepare educators to be aware of what student assessment will look like for Common Core. In a study of students enrolled in elementary and special education methods courses and children's literature courses Pae, Freeman, and Wash (2014) had the students take a fifth grade Common Core assessment, complete a written survey about the assessment, and then conduct a focus group interview. The sample consisted of 19 elementary education majors and 10 special education majors. What they found was that overall the students received a test score of $78.2 \%$. Five of the students $(17 \%)$ got below $70 \%$ on the assessment. If these students were more familiar with the content then they possibly could have been more successful with the assessment.

When asked questions on the survey and in the focus group it appeared that these students felt the test was fair and appropriate for fifth grade students (Pae, Freeman, \& Wash, 2014). Although they felt the assessment had too much writing and some unclear directions, more than $90 \%$ of them felt that fifth graders would do average or above average on the test.

Teacher candidates need time to become familiar with new standards and assessments. Being familiar with these practices will help them to be more confident in their classrooms when they become teachers. Zhang (2014) also argues that preservice 
teachers need time to get to know the standards, examine successful lesson plans, and collaborate with experienced teachers that are familiar with the standards. Teacher preparation programs are where teachers need to gain strong content knowledge and pedagogy, which are components of effective teacher preparation programs (Cooper \& Alvarado, 2006).

\section{Changes to Higher Education}

It could prove difficult to change the curriculum at colleges and universities as faculty members often have control over the content they teach which may make it harder to get everyone on the same page (Sawchuk, 2014). Some professors in higher education may not be familiar with the standards and that would make it harder to implement (Nelson, 2013). Another reason some professors may be concerned about changing their course criteria is because Common Core seems to be trying to make immense changes to teacher preparation programs, which could make some experienced teachers wary.

One way the CCSS are impacting higher education is through a two-year pilot project created by the Council of Chief State School Officers, whose members helped develop these standards. This pilot project is working with seven states on requiring accredited teacher preparation programs to be more selective in their induction process, changing licensure processes, and changing the way states evaluate and certify programs (Weiss, 2015). While we do need to have high standards for teacher preparation programs, it is never easy to partake in change. It is especially not easy when the people involved in the change are limited by several factors such as state legislatures and unclear interpretations from the state regarding new standards (O’Brien, 2013). McKee, Bell, and Kilbane (as cited in O'Brien, 2013) note these challenges, but stress "the goal of teaching 
is to equip teacher candidates, and ultimately their students, with the ability to develop learners who effectively use creative and complex thinking" (para. 23). This goal must not get lost among the expectations of Common Core.

\section{The Future of Common Core Mathematics}

Although some educators, parents, and government officials may dislike the new standards, Common Core is here for the time being. With teachers being asked to lead students in curriculum based on a set of new, more rigorous standards, the programs preparing these teachers need to be ready to produce confident and knowledge-rich teachers. In order to meet those lofty goals of teacher preparation, higher education needs to consider collaboration with educators and content within the standards (Jones \& King, 2012).

\section{Collaboration with Educators}

One thing that needs to be considered is collaboration within the program of teacher preparation. Hill, Stumbo, Paliokas, Hansen, and McWalters (2010) mention that in order to have rigorous and relevant learning take place there must be collaboration among teachers. This collaboration is especially necessary since the new standards are introducing pedagogical content knowledge that has not been stressed in the past. Many teachers, not only preservice teachers, will need more preparation for the math content involved in the Common Core standards.

If universities are working with local schools then they can help all teachers increase their content knowledge. The state of Utah has a great example of collaboration when in 2011 they trained educators in each of their districts on pedagogical content knowledge. Those educators that were trained then had to teach their colleagues in 
smaller groups (Sawchuk, 2012). This is one example of how collaboration can be used to help educators increase content knowledge.

\section{Content Within the Standards}

Another area that higher education should consider is content. With the content in high school changing, colleges and universities need to consider what incoming freshmen have already learned and how they can reinforce that learning (Association of Public and Land-Grant Universities, 2011). In order to progress learning that students have already received in high school, the curriculum in the colleges should align with the high school curriculum (Jones \& King, 2012).

As far as teaching mathematics, preservice teachers need to be taught how to teach the content and also the pedagogy (Superfine \& Lee, 2014). Higher education will need to examine the new standards and see how they can ensure teachers are prepared for CCSS (WICHE, 2011). The Conference Board of the Mathematical Sciences revised The Mathematical Preparation of Teachers, a document they originally released in 2001, to incorporate the CCSS (Association of Public and Land-Grant Universities, 2011). The revised document, Gearing up for the Common Core State Standards in Mathematics (2011), gives educators suggestions for starting points in professional development. Five initial domains within the standards were chosen as starting points for professional development. With each domain, suggested starting points are given to help teachers in deciding what to focus on. Institutions of higher learning could regard this document when implementing courses. 


\section{Is Teacher Preparation Changing?}

With all of these ideas on how to change higher education to accommodate CCSS for preservice teachers the question remains as to whether or not higher education is changing. While a 2013 study from the National Council on Teacher Quality shows that fewer than one in nine elementary programs and just over one-third of high school programs are preparing candidates with content rigorous enough to lead them to be able to teach CCSS curriculum (Greenberg, McKee, \& Walsh, 2013), Paliokas (2014) claims many states such as Arkansas, Massachusetts, and Washington are aligning their teaching preparation curricula to Common Core standards.

California is also making changes to teacher preparation programs. Patricia Swanson from San Jose State University sees her students grasping more of the pedagogy behind mathematics now and in regards to the CCSS she states, "The idea is to give young elementary school students different strategies to figure out math problems so they're not so dependent on memorizing formulas" (Baron, 2014, Excited About Math section, para. 8).

Education faculty at California State University in Long Beach also made it a priority to include an interdisciplinary focus in teacher preparation when redesigning the program in order to fit the interdisciplinary focus of the CCSS (Baron, 2014). To make sure that preservice teachers at all levels were prepared for the critical thinking component of CCSS they included that into all subjects for teacher preparation.

Professors at Tulane University in Louisiana are also changing their teacher preparation programs by having students study the common core standards and design 
lessons using them (O'Brien, 2013). By becoming familiar with the standards the students are more prepared when they enter the teaching field.

Not only do elementary and high school teachers need professional development regarding CCSS, but professors in higher education do as well if they are going to be teaching these standards to preservice teachers (Jones \& King, 2012). Paliokas (2014) identified how states have worked to align their teacher preparation curricula to the CCSS. One common approach she noted was supporting faculty through professional development. She found that North Carolina has provided professional development for college and university teachers on CCSS and Kentucky created CCSS professional development modules for higher education faculty. Along with professional development, teachers in higher education also need resources, which is why the Tennessee Higher Education Commission recently worked on creating resources for education preparation programs that incorporated the CCSS (Paliokas, 2014).

All of these examples point to the idea that teacher preparation is changing in the face of Common Core. In order to meet the needs of the teachers they are preparing, institutions of higher education may be finding that change is a necessity.

\section{Conclusion}

The CCSS for mathematics have changed the classroom curriculum from one with a focus on content to one that balances content knowledge with procedural knowledge (Dunkle, 2012). Not all preservice teachers have experienced this type of learning themselves growing up, and because of that they need extra guidance in this style of teaching and learning. Preservice teachers need to be prepared to engage new 
methods of solving problems and know how to help their students discover these methods.

Providing preservice teachers with a stronger focus on pedagogical content knowledge could help them in the classroom to be more confident teachers who are able to provide their students with a variety of solutions for each problem. Whether or not Common Core is here to stay is irrelevant; but providing strong content and interdisciplinary curriculum are both positive and will benefit students in any teacher preparation program.

In this chapter the researcher investigated the literature related to Common Core Standards for Mathematics and mathematics methods courses. Literature linking these two concepts was also explored. In the next chapter the methodology will be examined and data collection and analysis will be explained in detail. 


\section{CHAPTER III}

\section{METHODOLOGY}

Having looked at the current research and existing theories regarding the topic of student learning, Common Core standards, and mathematics curriculum in the previous chapter, this chapter will focus on the methodology in the research completed for this dissertation. Since the implementation of the CCSS in 2009 (Rust, 2012) there has been a shift in mathematics education towards more conceptual learning along with procedural understanding (Burns, 2013). With this change in mathematics education, how are places of higher learning addressing these standards for education majors within their mathematics methods courses? This qualitative, phenomenological research study explored how a large, midwestern university was addressing CCSS for mathematics within their elementary and middle level education mathematics methods courses.

\section{Research Questions}

The purpose of this research was to examine the degree to which one university was incorporating Common Core mathematics within their elementary and middle level mathematics methods courses. The research questions driving this study are: (1) In what ways do university professors address Common Core standards for mathematics in elementary and middle level mathematics methods courses? (2) How do elementary and middle level education majors describe their experiences with Common Core standards in their mathematics methods courses. 
As was noted in the current research, CCSS for mathematics seem to focus more on the conceptual ideas behind mathematics (Common Core State Standards initiative, 2015b; Dunkle, 2012). With standards that force students to explain why mathematics "works" in certain ways instead of just showing what they did, teachers need to be prepared strongly in content knowledge (Zhang, 2014). Mathematics methods courses commonly address pedagogical practices that teachers will need to be familiar with in order to feel more comfortable teaching mathematics (Burton, Daane, \& Giesen, 2008).

This research examined how the CCSS for mathematics had been addressed within mathematics methods courses. Professors and preservice teachers at a midwestern university were asked to describe their experiences with CCSS for mathematics within their mathematics methods courses. This was done to provide some insight into what experiences elementary and middle level majors, as well as mathematics methods professors, have had with CCSS for mathematics.

\section{Research Paradigm}

Through this research the elementary and middle level mathematics methods courses at a university were explored to see how Common Core standards for mathematics have been addressed within the curricula. Phenomenological research examines interactions taking place within certain lived experiences (Bogdan \& Biklen, 1998; Hatch, 2002). A phenomenological approach was utilized throughout this exploration since the researcher explored specific encounters and interactions with Common Core mathematics that preservice teachers were experiencing within their mathematics methods courses. 
This phenomenological research fits most closely with a constructivist paradigm (Hatch, 2002). In constructivism the belief is that knowledge is constructed by a person's experiences and personal interpretations of those experiences (Flick, 2004). The professors and preservice teachers who participated in this study were constructing their own knowledge about how Common Core standards are addressed within their mathematics methods courses. This research study gained insight from each of their perspectives on this topic in order to understand better how CCSS for mathematics have been addressed. Since the knowledge constructed by the professors and preservice teachers was what guided this research and allowed the findings to be created, the paradigm utilized was constructivist (Guba \& Lincoln, 1994).

\section{Type of Study}

Since this study examined a program already in place and looked deeply at how elementary and middle level education majors described their personal experiences it lends itself to a qualitative, phenomenological study (Denscombe, 2003). For this study, the phenomenon being explored was the extent to which the CCSS are being addressed within mathematics methods courses at a university.

The culture examined throughout this study consisted of preservice teachers in elementary and middle level education mathematics methods courses and their professors. That culture was believed to be part of the research process since data was collected while these mathematics methods courses were taking place (Hatch, 2002). In this research project, a culture's ideas, beliefs, and attitudes were explored.

The results of this study are not going to be used to generalize other educational institutions. For that reason, a North American view of phenomenology was utilized. The 
North American version of phenomenology comes mostly from the ideas of Alfred Schutz who was interested in how humans make sense of their experiences (Denscombe, 2003). This version of phenomenology focuses on describing ways that people give meaning to their experiences. Schutz studied social science and wrote The Phenomenology of the Social World in 1932 (Natanson, 1970). He adopted many ideas from Edmund Husserl (Hitzler \& Eberle, 2004), more commonly the idea of the lifeworld, which Husserl claims is "the human world of human experience as interpreted by man which is continuously in the process of becoming in the course of history" (Marx, 1970, p.70).

Schutz believed that the life-world perceptions were connected to our subjective consciousness and thus subjectivity is unavoidable, but that meaningful connections can still be made (Hitzler \& Eberle, 2004). Throughout this study, the participant responses were analyzed for understanding and connections in regards to the use of CCSS for mathematics within their mathematics methods courses. The researcher hoped to gain an understanding of their perceptions regarding how these standards are used within their courses. While subjectivity exists, since as Peshkin (1988) notes, “...one’s subjectivity is like a garment that cannot be removed" (p.17), the researcher focused on interpreting the experiences of these participants through their eyes and real-world occurrences.

\section{Data Collection and Analysis}

In this study data was collected through the use of personal interviews, an online survey, and document analysis. University professors were contacted via email with the use of a faculty recruitment letter (see Appendix A) or by phone using a telephone script for faculty recruitment (see Appendix B). They were asked whether or not they would be 
willing to participate in a personal interview and if the university professor agreed to the interview a time and date was determined. In the interview they were asked open-ended questions regarding the teaching methods they employ in mathematics methods courses (see Appendix C). These interviews were transcribed. The researcher then used open coding and highlighted related topics in order to find common themes (Biddix, 2009).

Education majors participating in an elementary or middle level mathematics methods course were sent a recruitment letter via email (see Appendix D) in which they were asked to complete an online survey of open-ended questions exploring their experiences in their mathematics methods courses (see Appendix E). At the end of the recruitment letter was a link to a survey, which was designed by the researcher on www.surveymonkey.com. Participants were allowed to skip questions. The results of the surveys were analyzed using open coding and by highlighting common themes (Biddix, 2009). This was done in an effort to see commonalities and differences between the individual interpretations in this phenomenological research study (Lodico, Spaulding, Voegtle, 2010).

Documents, which consisted of class syllabi and project rubrics from the courses, were also examined to see how the CCSS are addressed. Descriptive coding was used for the documents in order to classify them within the common themes found through open coding (Saldaña, 2009). Not all of the professors interviewed provided the researcher with documents. Table 1 shows what data was collected from each participant. 
Table 1

Data Collected from University Professors

\begin{tabular}{llll} 
Pseudonym & Personal Interview & Syllabus & Course Projects \\
\hline Jonathon & $\mathrm{X}$ & $\mathrm{X}$ & $\mathrm{X}$ \\
\hline Tricia & $\mathrm{X}$ & $\mathrm{X}$ \\
\hline Christine & $\mathrm{X}$ & $\mathrm{X}$ & $\mathrm{X}$ \\
\hline Heather & $\mathrm{X}$ & & \\
\hline Melissa & $\mathrm{X}$ & & \\
\hline
\end{tabular}

All three forms of data were analyzed further using a construct table. Miles, Huberman, and Saldaña (2014) suggest using a construct table for phenomenology because it allows the researcher to focus on one phenomenon. In a construct table a key concept can be explored by organizing the products of that concept that have been found in the data. Having data in a table allowed the researcher to easily look for variability across data (Miles, Huberman, and Saldaña, 2014). This allowed the researcher in this study to look at the experiences with CCSS for mathematics among the participants and gave the researcher a strong idea of how CCSS for mathematics are being addressed within these mathematics methods courses.

\section{Research Setting}

The research in this study took place at a large, midwestern university. At this university there are more than 25 undergraduate education programs, which include early childhood education, elementary education, middle level education, and secondary 
education programs. Teacher preparation is very important at this university as it is one of the largest teacher preparation institutions in the nation. This devotion to teacher preparation can be seen in the enrollment numbers, with over 3,000 students participating in the College of Education.

The interviews all took place on campus. Online surveys were sent to the school emails of all preservice teachers participating in the elementary and middle level mathematics methods courses during the semester of data collection. During the semester of data collection there were five sections of the elementary mathematics course and two sections of the middle level mathematics methods course.

\section{Sampling Strategies}

For the purpose of this examination, elementary and middle level education majors participating in a mathematics methods course and the professors teaching them were the sample. Since the sample was homogeneous and consisted of professors and preservice teachers enrolled in a current mathematics methods courses, purposive sampling was used (Denscombe, 2003; Hatch, 2002). Forty elementary and middle level education majors chose to participate in the online survey. Among the elementary education majors participating there were 20 preservice teachers that completed the survey; nine of them completed all of the questions and 11 skipped at least one question. Out of the 20 middle level majors that completed the survey 10 of them completed all of the questions while 10 skipped at least one question.

A sample of five college professors teaching mathematics methods courses was used for this study. For the purpose of this paper the researcher will be providing a pseudonym for the professors that were interviewed. Table 2 provides a list of the 
pseudonyms that will be used along with the gender of that professor and which course he or she taught. Three of the professors taught the elementary methods course and two of the professors taught the middle level methods course. Those professors were found using purposive sampling since it was necessary that they were currently teaching a mathematics methods course during data collection.

Table 2

Pseudonyms for Sample of University Professors

\begin{tabular}{lll} 
Pseudonym & Gender & Methods Course Taught \\
\hline \hline Tricia & Female & Elementary \\
\hline Heather & Female & Elementary \\
\hline Melissa & Female & Elementary \\
\hline Jonathon & Male & Middle Level \\
\hline Christine & Female & Middle Level \\
\hline \hline
\end{tabular}

\section{Instruments for Data Collection}

The instruments used in this research were surveys, interviews, course documents, and journals. In phenomenological research a lived experience is explored through the eyes of the culture living that experience (Hitzler \& Eberle, 2004). For this reason, an interview with first-hand accounts is often used in phenomenological research (Creswell, 2013; Hatch, 2002). Creswell (2013) also mentions that document analysis is sometimes used with phenomenological research as a way to gain first-hand knowledge of a 
culture's experience with a specific phenomenon. Each instrument was used to obtain evidence for how the CCSS for mathematics were being addressed in methods courses.

Preservice teachers enrolled in the methods courses were asked to complete an online survey. The survey consisted of five open-ended questions asking students about their knowledge in regards to the Common Core Standards for mathematics and how they have used the standards in their mathematics methods course. The last three questions were demographic questions to better understand the population being studied.

Personal interviews were conducted with three elementary math methods professors and two middle level math methods professors. These interviews lasted approximately one-hour and consisted of six open-ended questions asking the participants about their knowledge regarding the Common Core Standards for mathematics and how they have addressed them within their mathematics methods courses. The first two questions were demographic questions to gain insight into the participant and the institution. The last question asked the participant to share any documents, such as class syllabi or project rubrics, used within their course that may be helpful to this study. Three out of the five professors interviewed chose to share documents with the researcher.

The documents shared were examined using descriptive coding (Saldaña, 2009). Using descriptive coding allowed the documents to be analyzed for their use of addressing the CCSS for mathematics. The interviews were transcribed by the researcher, analyzed using open coding (Biddix, 2009), and then put into a construct table to examine more closely how CCSS were addressed within the mathematics methods courses (Miles, Huberman, and Saldaña, 2014). Online surveys were organized and analyzed using open 
coding. These surveys were then put into a construct table in order to see similarities or differences among the responses.

In order to address any personal biases the researcher may have had in regards to this topic a personal journal was used throughout this research (Watt, 2007). The journal was used solely by the researcher and provided a way to organize personal thoughts and reflections.

\section{Ethical Issues}

As with any type of research, there is the possibility of having bias in a qualitative study (Mehra, 2002). The important thing is to recognize it and be aware of it throughout the study (Bogdan \& Biklen, 1998). In a phenomenological study it is important for the researcher to step back from some of their thoughts and ideas so they can see the true phenomenon being studied (Denscombe, 2003; Watt, 2007).

\section{Positionality}

In order for this researcher to be able to focus on the true phenomenon being studied, it was important to address her positionality. This researcher is a White, heterosexual woman who has been involved in teaching elementary and middle level students for the past 14 years. The majority of that teaching was in a middle school mathematics classroom where this researcher was involved with the implementation of CCSS for mathematics.

When this researcher began teaching middle school mathematics she was very familiar with the NCTM Principles and Standards for School Mathematics (2000) and incorporated those standards within her mathematics classrooms. With the implementation of CCSS in 2010, this researcher saw many similarities between the 
Common Core Standards for Mathematical Practice and the current NCTM standards she was utilizing. Since these "new" standards seemed more familiar to what this researcher was already using she embraced these new standards within her mathematics classrooms.

Over the past few years this researcher has encountered many parents, friends, and educators that have spoken negatively about the CCSS for mathematics. Even with negative feedback at times, the position of this researcher towards CCSS is that it is a positive move for mathematics education.

\section{Reflexivity}

After addressing one's positionality, it is important to examine the relationship between the researcher and the research sample. Reflexivity suggests there is no way to make qualitative research fully objective (Denscombe, 2003). In qualitative research the data collection is the researcher, which means that there is a "...likelihood that the researcher's own subjectivity will come to bear on the research project and any subsequent reporting of findings" (Bourke, 2014, p.2).

As a middle school mathematics teacher the researcher had experience in implementing CCSS for mathematics and had also come across many varying viewpoints in regards to the standards. While some people had negative comments to make in regards to the standards, many of the comments spoken to the researcher by middle school teachers were positive (Schwartze \& Hatch, 2015). In order to maintain that this research focused only on the phenomenon of mathematics methods courses and how they have incorporated the CCSS for mathematics, the researcher had to leave all of those opinions out of the research. 
One way this was addressed was through the use of a research journal (Watt, 2007). The researcher continuously took notes in her journal throughout the research process in hopes of being reflective regarding her beliefs on this topic and new insights and information gained throughout this process. This process of reflection helped the researcher to become more aware of her personal biases and assumptions regarding this topic (Lodico, Spaulding, \& Voegtle, 2010). Hatch (2002) advises that all qualitative researchers keep research journals as it allows them the opportunity to constantly reflect on their own attitudes and feelings in regards to the research.

Having a familiarity with the standards, though, was helpful to the researcher in this instance. The experiences that the researcher had with the CCSS helped as those experiences assisted her in interpreting the phenomenon and allowed for adaptations as needed (Merriam, 1998). The researcher was aware of the CCSS for mathematics and, having taken mathematics methods courses for her undergraduate degree, she was aware of the purpose behind mathematics methods courses. Although all mathematics methods courses are taught differently depending on the professor, the idea that preservice teachers are being prepared to teach the subject of mathematics by gaining pedagogical knowledge is the same for the majority of mathematics methods courses (Burton, Daane, \& Giesen, 2008).

The researcher served as the primary investigator who recorded the phenomena and persons being studied (Hatch, 2002). Interviews, surveys, and document analysis were the methods of data collection. By taking on the researchers past understandings of CCSS and mathematics methods courses and incorporating them with new perspectives 
gained through interviews and surveys, the phenomenon was thoroughly studied and a deeper understanding obtained (Merriam et al., 2001).

\section{Trustworthiness and Reliability}

Some researchers argue that in qualitative research the term validity should not be used because it is more of a quantitative term, but they still see a need for checking whether research is valid (Golafshani, 2003; Miles, Huberman, \& Saldaña, 2014). For this study, the term trustworthiness will be used in place of validity.

When conducting research it is important to make sure data are trustworthy, or that they truly represent the phenomenon being studied. This is especially important in phenomenological research because the purpose is to describe someone else's encounter with a phenomenon. It is important that the study accurately reflects participants' experiences. If this is not done one is left with stories that are not truthful regarding the situation being studied (Miles, Huberan, \& Saldaña, 2014).

To maintain trustworthiness of this study the researcher needed to ensure that her findings were credible and that they make sense. The way that the researcher did this was by triangulating the data (Denscombe, 2003). Triangulation allowed the researcher to compare interview data, survey data, and documents to ensure that a true story was being told with the research (Miles, Huberman, and Saldaña, 2014). Comparing these three sources of data for corroboration allowed the findings to be more trustworthy; however, Miles, Huberman, and Saldaña (2014) do caution that it is important to look for inconsistencies within data and to try to understand those if they come up.

When conducting a research study it is important to consider not only the validity of the results, but also the reliability. When looking at the reliability it is important to ask 
if the results are consistent, or rather "if someone else did the research would he or she have got the same results and arrived at the same conclusions?” (Denscombe, 2003, p. 273) This can be difficult in qualitative research as it is impossible to generalize the results to other populations as the sample sizes are smaller and relate to a specific group of individuals (Shenton, 2004). With reliability being more difficult to attain in a qualitative study, Lincoln and Guba (1985, p. 300) chose to refer to reliability as “dependability” in qualitative research.

In order to check dependability during this phenomenological study the researcher took extensive notes and provided clear descriptions of the aims within the research, theory, how data were collected, and how they were analyzed. By keeping good records one can check to make sure the results were dependable and trustworthy (Denscombe, 2003).

Another way that dependability was ensured is by explaining in detail the methods used to obtain the results. In describing the research process, this allows other researchers to repeat the study in order to see whether the results obtained are similar thus maintaining reliability, or dependability, within the study (Shenton, 2004).

\section{Significance of Study}

The CCSS for mathematics are still fairly new, but are becoming much more prevalent in elementary, middle, and high schools around the United States. While current teachers in $\mathrm{K}-12$ classrooms are being provided with some professional development regarding CCSS implementation is that development being done with preservice teachers? This research examined how one university was addressing CCSS within their mathematics methods courses and looked at whether or not preservice 
teachers were feeling prepared to implement the CCSS in mathematics within their own future classes.

\section{Conclusion}

The phenomenological research described in this chapter sought to examine how one university was addressing the CCSS for mathematics within their mathematics methods courses. Introduced in 2010 the CCSS for mathematics have put a focus on demonstrating and explaining understanding in the mathematics classroom (Burns, 2013). Mathematics methods courses provide preservice teachers with content knowledge as well as pedagogical practice (Burton, Daane, \& Giesen, 2008). Are mathematics methods courses in higher education addressing these new standards for mathematics in order to ensure preservice teachers are prepared to use them in their teaching? Through the use of interviews, surveys, and document analysis this research examined this topic further.

In the next chapter the researcher will examine the findings based on data collection and analysis. The findings were organized into themes and each theme will be explored in detail. The findings are then linked to the conceptual framework. 


\section{CHAPTER IV}

\section{FINDINGS}

The purpose of this study was to explore how one university is addressing Common Core State Standards (CCSS) for mathematics within their mathematics methods courses. Common themes emerged within the professor interviews and the student surveys that provide insights into how the CCSS are being addressed within the elementary and middle level mathematics methods courses at this university. These themes will be explained further in this chapter and implications for educators and preservice teachers based on this research will be suggested.

\section{Description of Sample}

Five university professors were interviewed regarding the math methods courses that they taught. Two of the professors were teaching the middle level math methods course which addresses sixth through eighth grade teaching. The other three professors interviewed were teaching the elementary math methods which focuses on curriculum in kindergarten through fifth grade. The professors had a range of experience at the collegiate level with the most experienced having taught at this university for 17 years and another professor having finished her seventh year teaching there. There were a variety of responses but some common themes seemed to form based on the responses. Refer to Table 2 in chapter three for the pseudonyms used for the professors as well as their gender and course taught. 
Preservice teachers enrolled in the elementary and middle level mathematics methods courses were surveyed online regarding their thoughts on how their methods course had prepared them for Common Core mathematics standards. Forty students were surveyed; 20 enrolled in the elementary methods course and 20 enrolled in the middle level methods course. In the survey responses from students in an elementary math methods course, nine completed all questions in the survey while 11 skipped one or more questions. Out of the 20 students responding that were taking a middle level math methods course 10 completed every question while 10 skipped one or more questions. The majority of the students surveyed had been at this university for three years (13 out of 19 that responded to this question). All of them were familiar at some level with the Common Core mathematics standards, although that familiarity was varied.

\section{Findings}

For the purpose of this analysis the researcher will examine the two research questions separately as one focuses on the university professors and how they address the CCSS within their methods courses and the other question focuses on the preservice teachers and how they describe their experiences with CCSS in their methods courses. Common themes will be investigated. Finally, the researcher will provide a summary of all data found and relate the findings to the conceptual framework.

\section{Research Question 1: In What Ways do University Professors Address CCSS for Mathematics in Their Math Methods Courses?}

When exploring the first research question, in what ways do university professors address CCSS for mathematics in their methods courses, the researcher examined the personal interviews with the professors and course documents that were provided by the 
professors. Open coding was done with the interviews and construct tables were then created using the interview transcripts (Biddix, 2009; Miles, Huberman, and Saldaña, 2014). The documents were analyzed using descriptive coding (Saldaña, 2009).

There were three main themes that were uncovered through the coding process. The first theme was classroom assignments. This was the most prevalent theme, as it seemed the CCSS were mostly being addressed within assignments. Another theme was preservice teacher expectations as some of the expectations that the professors had for their preservice teachers addressed topics from the CCSS. The final theme found was language. Several of the professors interviewed brought up the idea of translating the CCSS and how they addressed that within their courses. These three themes will now be explored further.

Classroom assignments. When looking at how these university professors were addressing CCSS for mathematics within their math methods courses the ways that they integrated CCSS for mathematics within their classroom assignments came up frequently. Lesson plans was one way that the CCSS for mathematics were addressed as students were asked to create several lesson plans, which they then presented in a clinical experience at the elementary level.

Although the preservice teachers were asked to include the CCSS for mathematics within their lesson plans, it seemed that mostly the content standards were represented and only one elementary methods professor, Melissa, mentioned addressing the Common Core Standards for Mathematical Practice. Melissa did not require that preservice teachers provide the practice standard but she stated: 
I try to point out when they're writing their lesson plans what standard of practice they are going to be using with it, though most of the time by that point they are just so focused on the content standards that they forget about bringing that in. Only one elementary methods professor (Tricia) provided me with documents from her course. Within those documents it was clear that she did require preservice teachers to include CCSS, but it is stated as the "Common Core Standards" and does not specify content or practice standards. Thus, the researcher infers that she means a content standard since they are the ones most frequently used within lesson plans.

Both of the middle level professors provided the researcher with a copy of their course syllabi. Upon examining both syllabi it seemed that the assignments varied but in general they both addressed similar assignments in their interviews. The researcher did note that both syllabi listed the six principles of mathematics from the National Council of Teachers of Mathematics' Principles and Standards for School Mathematics (2000), but not the Common Core Standards for Mathematical Practice.

Within the syllabi and the interviews, it was clear that Christine was addressing the CCSS for mathematics through the use of content and mathematical practices whereas Jonathon seemed to be focusing more on content. Jonathon noted:

I probably was not as strong in that [addressing practices] this semester because I think the hard part is if you look at the way I teach and what we do we cover those things but to make them specifically point out which ones they were, not so much.

This statement makes it clear that while Jonathon may not be explicit in asking preservice teachers to specify what mathematical practices they were addressing, he felt 
that he was covering the mathematical practices sufficiently enough throughout the coursework.

Christine, on the other hand, clearly focused on standards for content and mathematical practices as she had listed on all of her assignment rubrics that students needed to provide the Common Core Standards for content and mathematical practices. She also said, "they not only have to identify the mathematical content standards and the mathematical practices that they are addressing in that lesson but they have to tell me when and how, and how that relates to the mathematical goals."

Tricia made it clear in the interview that she addressed the practice standards from Common Core within her elementary courses. She stated, "I try to mimic some of the eight practice standards, so we talk about are there other ways of doing it [solving problem], is it mathematically correct, how would we then assess this solution strategy?" Her classroom assignments seemed to consistently address the CCSS for mathematics.

The Standards for Mathematical Practice, which describe how a mathematics classroom would look if one were incorporating CCSS for mathematics, describe students persevering on problem solving, reasoning abstractly, and modeling with mathematics (Common Core State Standards initiative, 2015a). In order to do this the teacher needs to guide students to understanding and let them struggle a little with the learning so they can persevere in order to find meaning. All of the elementary professors interviewed mentioned having a classroom assignment where the preservice teachers needed to distinguish between more traditional teaching and research-based teaching. They also all mentioned trying to get their preservice teachers to focus on less direct teaching, although that seemed like a hard notion for them to grasp. Melissa said: 
[The preservice teacher's] job is to provide word problems and then come up with questions that will help guide student discussion to lead to different solution strategies, that's the ultimate goal at least. Some of them have trouble getting past the teaching is direct instruction aspect.

Professors did seem to be bringing up classroom discussions involving the CCSS for mathematics in talking about the importance of having their students struggle with mathematics and the need to write meaningful tasks. Tricia stated:

We had a small conversation in the classroom about allowing children to struggle with their math knowledge and why that is beneficial to allow them to struggle with it and how to ask questions to help them, to help ease their struggle without just telling them how to do it.

This "struggle" that students sometimes have in mathematics supports the ideas presented in the Standards for Mathematical Practice that students must persevere in their problem solving.

Tricia and Heather both mentioned having assignments where preservice teachers were given two vignettes: one traditional teaching and one research-based teaching. The hope was that the preservice teachers would be able to see differences in the two methods of teaching and hopefully see merit to the research-based method of teaching. What they found was the opposite, though. Heather found that preservice teachers liked both methods of teaching:

They read two different vignettes, one very traditional, direct teaching type and the other is the total opposite, like problem solving and all kid based. I pick very 
starkly contrasting episodes and have them read and then comment on them. They [the preservice teachers] are like, they both are good.

Tricia found similar results when her preservice teachers could not initially see a difference in a traditional curriculum versus a research-based curriculum:

So they had to look at lesson plans from a traditional curriculum and lesson plans from Everyday Math and we talked about the differences in the lessons, the differences in the activities, the differences in the homework assigned, the differences in the tests for those two different curriculums. And it struck me odd that they couldn't tell, initially, could not tell the difference between the two. So that was really disappointing.

Through these examples it seems that the CCSS for mathematics, which is a research-based set of standards, is being addressed within these classroom assignments but that preservice teachers are struggling with identifying characteristics of a researchbased curriculum. This struggle does not seem to be a new one, though, and Heather describes it as, “[They] don't have experience working with kids so it's like, you've never eaten apples or pears, you just read about them, they all look the same in the pictures." Until preservice teachers get more experience in a classroom, the elementary methods professors seemed to think that identifying Common Core standards and research-based type of teaching would be more difficult for them.

Jonathon brought up that the CCSS had changed one of his assignments in his middle level math methods course. He stated that in previous years of teaching this course he had completed a textbook analysis with preservice teachers. What he found this year, though, was that a lot of local schools were getting rid of their math textbooks 
because they did not match Common Core standards. Since he found that out he decided to drop the textbook analysis assignment.

Classroom discussions from both professors in the middle level seemed to revolve around the idea of levels of cognitive demands of tasks. Smith and Stein (1998) claim there are different levels of tasks in a mathematics classroom and that middle school students have higher learning gains when they are involved in high levels of cognitive thinking and reasoning. The four categories of cognitive demand that Smith and Stein address are: memorization, procedures without connections to concepts, procedures with connections to concepts, and doing mathematics. Jonathon said, "We do talk about levels of cognitive demands of tasks so we analyze different tasks and they work on challenging tasks."

Christine provided the researcher with a copy of an assessment for the clinical experience. In the assessment she asks that preservice teachers identify mathematical goals and cognitive demand of tasks. Christine also mentioned, "I debrief with my students sometimes...did you keep the cognitive demand of the tasks or at some point was it reduced for a variety of tasks?" She says that over the course of the semester preservice teachers are asked to reflect upon what level of tasks they are addressing and whether or not they are including challenging problems for their clinical students.

Classroom assessments were another place where the CCSS were being addressed. Tricia was the only elementary participant that provided the researcher with copies of documents detailing the assessments, but Heather did show the researcher a copy of the final assessment for her course which did ask students to list the problem type 
shown along with the strategy type being used. Preservice teachers then had to analyze the lesson using the CCSS for mathematics.

While Melissa did not provide a copy of an assessment to the researcher she did say:

After I wrote my final I was reading through it thinking about this interview because one of my questions is regarding a content standard about how the Common Core Standards, multiple standards, talk about students solving arithmetic problems based off of properties of operations and place value, then I ask them what solution strategies that we have talked about would meet those standards for addition, subtraction, multiplication, and division.

It is clear that the CCSS for mathematics, content and practice standards, are being addressed within the classroom assignments for these elementary math methods courses. The ways that these standards are being addressed within the classroom assignments are through lesson plans, other classroom assignments, discussions, and assessments.

Preservice teacher expectations. Through discussions with the professors it was clear to the researcher that CCSS were being addressed through the expectations that the professors held for their preservice teachers. The expectations that most closely aligned with the CCSS were those of perseverance, constructing viable arguments, and attending to precision.

Perseverance was mentioned by all five professors in a sense that they were asking the preservice teachers to allow students to struggle with the work and telling 
them that it would take more time, but that the extra time was acceptable because in the end it would be more beneficial to the students. Tricia noted:

I want you [preservice teachers] to understand that you have to work your tail off to do these things, but you do it because it's the right thing to do. You know you don't go for the easy way out, go for the way that's best for the kids. So we talk about that a lot in the classroom and how that plays out in those eight mathematical practices for Common Core. We're trying to get people, it's like trying to get people to eat the right foods. I talk about that all the time. If you're eating healthy it takes more time to cook and eat healthy then to get out an already processed meal and warm it up in the microwave. You know, it takes time to do things the right way but the benefits outweigh the time you put into it.

The first standard listed in the Standards for Mathematical Practice is "make sense of problems and persevere in solving them" (Common Core State Standards initiative, 2015a, $\mid 2)$. CCSS for mathematics wants students to understand the meaning in the mathematics. To do that students sometimes need to struggle with the mathematics before finding meaning.

One issue that came up through the interviews was that preservice teachers lack the experience of working with students so they are unaware of what students are capable of in terms of their work. Heather stated:

They don't believe many kids can do it and they think it would be too long of a wait so they want to dissect the problems for them so that when it comes to the kids they are getting the same three times five as they first wrote so that they never have to, I guess, struggle figuring out the problem itself. 
Jonathon also mentioned that his preservice teachers often underestimate what the students are able to do and tend to just tell them the answers or not engage them in discourse. Comfort is another reason why he felt preservice teachers did this, because they had not previously had experience in a classroom setting so this was their way to handle discomfort from the unknown. Jonathon said:

We try to model the same type of teaching that we hope they would do in the classroom, so we try to give them rich problems and engage in discourse. It's like, why didn't you do that with the kids? We do all this stuff. They're like, yeah we are adults we can handle that; they can't.

Christine brings up the idea of following your students' thinking and she stresses that to her preservice teachers. She says:

To some people it's about getting through the book or getting through a chapter and to me, I mean, I think that was one of the goals of the writers of the Common Core, was that they were trying to scale it down so these three to five things, if you zoom in here great, it's going depth over breadth, and we talk about that. Each of the professors in this sample seem to be teaching preservice teachers that struggling is not a bad thing in mathematics. Melissa claims that she is constantly telling her preservice teachers that their teaching needs to be more about depth and not so much getting through the material. She tells them, "Hey, if you get through two problems and they were deep problems then your students are touching on this and your students are touching on this." The "this" that Melissa talked about referred to the Standards for Mathematical Practice addressed in the CCSS for mathematics. 
The third Standard for Mathematical Practice claims that students should be constructing viable arguments regarding mathematics. All three professors interviewed for elementary methods seemed to be addressing this with their preservice teachers by encouraging dialogue in their classrooms and in clinical situations. They all seemed to have the expectation that preservice teachers should be going into their clinicals and using the same type of dialogue they used with them in the methods classroom. Melissa says she tells her preservice teachers:

Look, this is what we are expecting your students to be able to do so if this is what we're expecting them to do that is what I'm expecting you to do. So, let's think about how we can do this. How are we going to create viable arguments? The sixth Standard for Mathematical Practice that is listed in the CCSS is about being precise with mathematics. While all of the elementary methods professors touched upon this preciseness, Tricia stressed it the most. She made it clear that her expectation for her preservice teachers was that they are specific with their mathematics. One example she gave was how in her classroom of preservice teachers she had given them a problem where they had 24 feet for the perimeter of something and they had to find the largest possible rectangle. Many preservice teachers did not put a six by six figure because they claimed that was a square and not a rectangle. That led this professor to spend time in the classroom discussing the definitions of square and rectangle in the hopes of addressing those gaps in their knowledge. Not being precise with one's mathematical language can lead to some of these gaps. Tricia goes on to say, "You are creating a misconception in your own children when you do not write with mathematical 
preciseness. When you are not completely mathematically correct, you know, that's where those misconceptions come from at the elementary level."

Language. The language of the CCSS for mathematics came up in two out of the three elementary methods professor interviews. Both Tricia and Heather brought up the fact that the CCSS were written by very mathematical people and thus the language used within the standards is sometimes difficult for preservice teachers to dissect. Both of these professors claim that they address this issue of language with their preservice teachers.

Tricia has preservice teachers match assessments from the Everyday Math curriculum with the Common Core Standards. She claims:

I want them to see a correlation between those Common Core Standards and the questions we ask kids in the classroom because often [preservice teachers] don't understand the language in the Common Core Standards, and I find that with practicing teachers too. The Common Core Standards were written by people who are really steeped in their research in math education.

Tricia feels like part of her job as a professor to these preservice teachers is helping them to understand what the CCSS for mathematics are saying because the language can be difficult for people that are not mathematicians to understand. Heather also noted that she felt it was her job to help preservice teachers understand the language within the CCSS for mathematics.

Heather finds, "They get so frustrated because it's so mathematical." To address that frustration she tells preservice teachers that it is not easy to understand these standards, but that if they take the time to learn what they mean then it can be their 
strength. She tells them, "You can't offer the experience that other teachers have but you can offer the knowledge that they do not have, so this is actually your strength."

Melissa did not bring up the language of the CCSS for mathematics as an issue that comes up with her preservice teachers, but she does show her preservice teachers several examples of teachers addressing the Common Core Standards and they talk about what it looks like.

The idea of language within the Common Core Standards came up less frequently with the middle level math methods interviews than it did in the elementary math methods interviews. Although both professors made small mention that the standards can be confusing in their language, it was not stressed as something that was addressed in their classrooms.

Jonathon brought up the idea that two people could read the same standards and still have different expectations on what it means. This was in regards to a question about whether the department guided professors in implementing the standards and he goes on to say, "I'm not sure how they could support us or what they could do anyways." Interpreting the standards from the viewpoint of his preservice teachers did not come up as something that was being addressed in his methods courses.

Christine did not bring up the issue of preservice teacher interpretations regarding the standards either. She only mentioned that she felt the Common Core Mathematical Practices were a little clearer in their expectations than the NCTM process standards.

\section{Summary of Results from Research Question 1}

When looking at the ways that university professors were addressing CCSS for mathematics in their math methods courses it was clear that both elementary and middle 
level math methods courses asked preservice teachers to provide the CCSS within their lesson plans. In the elementary methods, though, the standard stressed was the content standard whereas in the middle level methods the content and practice standards were both addressed within the lesson plans.

To address the Common Core Mathematical Practice Standards preservice teachers in both methods courses were presented with challenging tasks and seemed to have numerous conversations about how to make sense of the problems, construct a viable argument, and critique the reasoning of others. All of these standards seemed to be addressed through the use of collaborative groups in many situations.

Preservice teachers were also able to model the mathematics they were learning through the use of clinicals in which preservice teachers took the lessons they wrote and applied them in a classroom setting. All of the professors interviewed seemed to stress to their preservice teachers the need to not focus solely on direct teaching but to engage students in their learning and provide meaningful tasks for them.

Both elementary and middle level math methods professors had expectations of their preservice teachers that they would provide students time to struggle in their clinicals. Several professors noted that this was a difficult one for preservice teachers to practice and the idea that maybe having a stronger content knowledge in mathematics and more experience in the classroom would allow preservice teachers to let their students struggle more.

The mathematical language of the CCSS for mathematics came up mostly in the elementary methods courses. The professors for those courses mentioned that they discussed with preservice teachers that the language of the Common Core can be difficult 
and words are sometimes misused. Tricia brings this up when she notes, "The phrase 'standard algorithm' is often misused in the common core standards." She goes on to say that:

If you look in all the documentation of Common Core Standards the phrase standard algorithm is defined to be any algorithm that is generalizable, whether it is a U.S. traditional algorithm or student invented algorithm. So, a lot of practicing teachers that I work with think that when they see the phrase standard algorithm that means we have to teach the U.S. traditional algorithm.

The professors in the elementary methods courses are trying to ensure that their preservice teachers are aware of these misconceptions presented in the language of the Common Core and are able to address those with their own students someday.

\section{Research Question 2: How do Elementary and Middle Level Majors Describe Their Experiences with CCSS in Their Math Methods Courses?}

Elementary and middle level majors were asked to complete an online survey regarding their experiences with CCSS in their math methods courses. They were allowed to skip questions and out of the 20 elementary majors that responded, 11 of them skipped one or more questions. Out of the 20 middle level education majors that responded to the online survey, 10 of them skipped one or more questions while 10 answered all of the questions. None of the data had identifiers so the respondents were anonymous. When analyzing the responses from the elementary and middle level majors regarding their experiences in their math methods courses, the theme of classroom assignments emerged. Within classroom assignments the idea of group tasks was noted 
frequently. Other experiences also evolved within the responses. These two ideas will be explored in more detail.

Classroom assignments. When asked to give examples of how the math methods course has prepared them for implementing Common Core math standards, seven elementary preservice teachers responded that they had to write lesson plans based on the standards. Eight out of the 10 middle level preservice teachers mentioned having to write lesson plans that aligned with the standards for this question. This seemed to be the most common example for how the math methods course had addressed the standards.

Middle level majors mentioned not only having to identify which standard they used, but they had to go further in supporting how they would address that standard in their lesson. One respondent said, "We had to specifically reference the Common Core standards when creating lesson plans and had to support how we were going to cover that particular topic in our lesson."

Other classroom assignments that came up were determining if a variety of strategies met the standards, examining curriculum that is aligned with the standards, looking at how to implement the standards and being able to implement them through clinical experiences, and examining a variety of problems. One preservice teacher noted: "We have worked hard to examine multiple forms of problems and multiple ways to solve those problems in order to fully be able to help our students."

Along with the assignments it seemed that group tasks were frequently used. In the elementary and middle level math methods courses there seemed to be considerable collaboration. This seems to fit into the Common Core Standard for Mathematical Practice that states students must "construct viable arguments and critique the reasoning 
of others" (Common Core State Standards initiative, 2015a, ๆ4). Two of the elementary preservice teachers mentioned utilizing this standard within their math methods course.

One elementary preservice teacher stated, "We often solved problems in ways other than the algorithm method and then discussed our results with the people at our table." This shows that students were given opportunities to critique each other and find various solutions for the same problem.

Another elementary preservice teacher said, "We worked together to solve challenging problems and discussed them as a class. We were also encouraged to use these same collaboration methods in our lesson plans and while teaching our students."

One middle level preservice teacher wrote, "Most, if not all, class periods heavily focused on working in collaborative groups." This preservice teacher then goes on further to say that the collaborative group tasks were very "meaningful." They state, "I never once had a feeling of being placed in a group just for the instructor to say they were incorporating group work."

Several respondents also noted that they were given challenging problems within their math methods course. One middle level preservice teacher said they were given problems, provided time to discuss them in groups, and then shared ideas with the whole class. This fits with the Common Core Standard for Mathematical Practice that focuses on constructing viable arguments and then critiquing the reasoning of others.

Classroom discussions also revolved around ideas from the CCSS for mathematics. One middle level preservice teacher responded, “....many class discussions focused on how standards could be addressed." Another said, "We have talked briefly 
about the organization of the standards." It was clear that there was discussion in the middle level math methods course regarding the Common Core standards.

Several preservice teachers brought up clinicals as a positive aspect of the math methods course because it provided them a place to practice what they were learning in their course.

Other experiences. While the majority of the comments from the elementary and middle level preservice teachers were positive regarding their experiences with CCSS in their math methods courses some comments were more negative. Some students felt as though the math methods course may not be fully preparing them to use Common Core Standards in their future math classes.

Two of the elementary preservice teachers brought up the fact that there just was not enough time in a semester long course to learn everything they wanted to regarding CCSS for mathematics. With only five clinical days provided, one elementary preservice teacher felt that it was inadequate in preparing for addressing the CCSS for mathematics with his or her students.

One middle level preservice teacher stated, "There is just simply not enough time in a semester to get to it all." A couple other preservice teachers brought up the idea that clinicals did not provide enough time for them to incorporate the type of challenging problems that the CCSS for mathematics requires. One middle level preservice teacher noted,

When teaching there were not opportunities for challenging problems because we had no clue what the students had already learned so we had to start from scratch. 
Going along with that there was not much time to where we could try and get more information on our students so this was a major set back.

Another elementary preservice teacher felt as though the preparation was not adequate before working in the clinicals. They stated, "I was asked to do these things with the students I worked with but I was not given time to do it myself or necessarily taught how to do it well with my students."

Other middle level preservice teachers mentioned that they would like more guidance in how to write challenging problems instead of just being given them to solve. Another middle level preservice teacher mentioned that the class could cover the standards with more depth. Finally, one middle level preservice teacher mentioned that there was a lack of explanation given regarding the standards. This person notes, "The standards are never explained. I feel like we are told to use them but never told what a lot of them mean." The middle school majors completing the survey seemed to be wanting a little more explanation regarding what the CCSS for mathematics mean and how to use them effectively.

One elementary preservice teacher stated, "This course has not helped me become prepared at all as far as teaching and implementing Common Core Standards.” This comment indicates that not all of the preservice teachers are coming out of their math methods course feeling confident about Common Core Standards. Another elementary preservice teacher stated, ““'We have only touched upon the Common Core Standards about twice."

While the majority of the preservice teachers completing this survey felt adequately prepared to incorporate the CCSS for mathematics within their teaching it is 
clear that not everyone shared these feelings. In general, $25 \%$ of the elementary students surveyed said they were very familiar with the Common Core math standards and 75\% said they were somewhat familiar. Out of the twenty middle level majors completing this survey, $75 \%$ of them felt somewhat familiar with the Common Core math standards and only $20 \%$ felt very familiar. Five percent of the middle level respondents felt they were not very familiar with the Common Core math standards, even at the end of their semester taking a math methods course.

\section{Summary of Results from Research Question 2}

For the second research question the researcher wanted to see how the elementary and middle level preservice teachers described the experiences they had with the CCSS for mathematics within the math methods courses they had taken that semester. The majority of elementary and middle level preservice teachers responding to this survey mentioned that their courses provided them with collaboration and the idea of aligning lesson plans to the CCSS for mathematics.

The elementary preservice teachers mentioned having to provide a standard for their lesson plans, while the middle level preservice teachers mentioned listing the standards and then including support for how they would cover that standard in the lesson. Collaboration in course work as well as clinical experiences came up repeatedly in responses from the preservice teachers. Several preservice teachers also mentioned having discussions regarding challenging problems and how to solve problems in a variety of ways.

Some preservice teachers did feel as though there was not enough time in the course to cover in depth how to effectively incorporate the CCSS for mathematics. Many 
mentioned that the clinicals were too short and there was not adequate time to allow students to struggle with meaningful tasks. This meant that there was less time to spend on reasoning and explaining, which is one of the groups in McCallum's (2011) diagram of the Common Core mathematical practices from chapter one. According to the mathematical practices in the Common Core, mathematics students should be encouraged to discuss a variety of methods for solving problems and to be able to critique each other's methods. Without time and not having the ability to meet with a class consecutively, this is difficult to fulfill.

Another group in McCallum's (2011) diagram refers to the overarching habits of mind of a productive mathematical thinker. Within this group is the idea that mathematics students should persevere in solving problems and be precise with their mathematics. The preservice teachers in these mathematics methods courses found it hard to allow their students time to persevere with having only a limited amount of time to meet with them. A few preservice teachers also brought up that the clinicals directed their lesson plans towards one grade level and content area so they would have liked to have been able to explore standards in other areas of mathematics than the one they were teaching for their clinical.

\section{Summary of Documentation}

The researcher asked all university professors that participated in this study if they would provide her with documentation from the course such as syllabi or course projects. Both middle level professors provided the researcher with a copy of their syllabus and examples of projects. Only one elementary professor provided the researcher with documentation that included course projects. 
From the provided documentation, it was clear to the researcher that CCSS for mathematics were being introduced and discussed in the math methods courses, as they were required on all lesson plans. In Jonathon's syllabus it also has listed "Teaching to the Common Core standards" as part of the topical outline. Discourse and collaboration, which are necessary when teaching Common Core (Hull, Miles, \& Balka, 2012), were also listed in some manner on the documentation. Tricia also noted justification, which is included in the Common Core Standards for Mathematical Practice, on her project rubrics.

\section{Findings Linked to Conceptual Framework}

The conceptual framework the researcher shared has a grouping of the Common Core Standards for Mathematical Practice (McCallum, 2011). McCallum (2011) groups the mathematical practices into four categories: reasoning and explaining, modeling and using tools, seeing structure and generalizing, and overarching habits of mind of a productive mathematical thinker. Within these groups he places the eight mathematical practices: make sense of problems and persevere in solving them, reason abstractly and quantitatively, construct viable arguments and critique the reasoning of others, model with mathematics, use appropriate tools strategically, attend to precision, look for and make use of structure, and look for and express regularity in repeated reasoning (Common Core State Standards Initiative, 2015a).

These standards for mathematical practice describe how to present the mathematics content. They also provide teachers with methods for students to learn the content standards (Common Core State Standards initiative, 2015a), similar to a methods course. Since this research specifically looks at mathematics methods courses and how 
preservice teachers are taught to convey mathematics standards, the researcher felt that McCallum's grouping most closely covered what would be addressed in the mathematics methods courses. This theoretical framework also provided the researcher with groups that could assist in data analysis. During data analysis, the findings were chunked into categories based on the groups from McCallum's diagram.

\section{Reasoning and Explaining}

Within this section of McCallum's (2011) grouping the standards for mathematical practice that are addressed are \#2) reasoning abstractly and quantitatively and \#3) constructing viable arguments and critiquing the reasoning of others. The researcher noted several instances of these standards being put into practice.

In order to maintain quantitative reasoning, mathematics educators should be addressing units, the meaning of quantities, and how to use different properties of operations (Common Core State Standards Initiative, 2015a). Tricia showed she was addressing this by her numerous examples of ensuring preservice teachers understood the mathematical language and were using it correctly with students. She gave an example of a discussion she had with her preservice teachers regarding square units:

[The preservice teachers] had no idea what a square inch meant and instead of calling them inches squared at the elementary level we should be calling them square inches because that's what they are. I said I understand that's a common notation [inches squared], but kids don't understand that notation, so how about we teach it for understanding versus teaching it for rote memorization.

All of the university professors also mentioned having challenging problems that preservice teachers were expected to reason through. This was also emphasized in the 
preservice teacher survey results as many of them mentioned that they were given challenging problems. When given these challenging problems, the preservice teachers were also asked to solve and then discuss their solutions. This addresses the standard of constructing viable arguments and critiquing others.

In the preservice teacher responses it was clear that collaboration was a key component of the mathematics methods courses. One preservice teacher stated, "We were given challenging problems, allowed to collaborate for an extended period of time, and then discussed as a class." Through these discussions the preservice teachers could critique other groups' reasoning and share their thoughts.

\section{Modeling and Using Tools}

The modeling and using tools section of McCallum's (2011) grouping addresses standards \#4) model with mathematics and \#5) use appropriate tools strategically. These particular mathematics methods courses include a clinical component where preservice teachers are able to go into elementary and middle level classrooms and present lessons to the students. When doing this they are able to practice modeling with mathematics and using appropriate tools. Some preservice teachers felt as though the clinical time was not enough, though, as can be seen in this response: “I don't think adequate time was something we had. We only had five clinical days with our students."

While the modeling and use of appropriate tools seemed to be covered within the methods courses, the university professors did seem to repeatedly mention how the preservice teachers at this level of their learning had difficulty putting these into practice since they had not been given much hands-on experience with these concepts yet. Several of the professors interviewed mentioned that their preservice teachers tended to lecture 
more to their students instead of letting them struggle with their learning. Jonathon says, “It's also a comfort factor. When you are trying to juggle all these things [in the classroom] it's just easier to tell the students all of the information and not open it up to something you don't know how to control." This could be one reason why these standards are harder for preservice teachers to practice in the methods course, but the standards are definitely being presented in these methods courses.

\section{Seeing Structure and Generalizing}

McCallum's (2011) framework includes mathematical practice \#7) look for and make use of structure and \#8) look for and express regularity in repeated reasoning within the section of seeing structure and generalizing. Preservice teachers in these mathematics methods courses were practicing these standards through the use of collaborative group work to solve challenging problems. It was clear through the interviews and surveys that challenging problems were a main component of these methods courses. Through these problem solving activities preservice teachers had to evaluate their results and discuss whether or not their results made sense or fit the patterns.

Preservice teachers were also encouraged to look at various ways of solving the same problem. One preservice teacher noted in the survey that, "We often solved problems in ways other than the algorithm method and then discussed our results with the people at our table." This allowed them to not just look at a general method for solving problems, but to explore different pathways to the same answer.

\section{Overarching Habits of Mind of a Productive Mathematical Thinker}

Within the section labeled "overarching habits of mind of a productive mathematical thinker," McCallum (2011) includes mathematical practices \#1) make 
sense of problems and persevere in solving them and \#6) attend to precision. These practices were definitely present within the mathematics methods courses. The idea of challenging problems came up from both university professors and preservice teachers as a major part of this course and preservice teachers were expected to persevere in solving them. While it was noted by university professors that the preservice teachers sometimes had difficulty putting this idea of perseverance into practice within their clinical experiences, it was being practiced in their methods course.

The majority of professors interviewed made a comment about how the preservice teachers struggled with allowing their students time to work on challenging problems. This seemed to be due mostly to their lack of previous experience within a classroom setting, which could lead to some uncertainty and anxiety for the preservice teachers. Heather also mentions, “[Preservice teachers] don't believe many kids can do the problems and they think it would be too long of a wait so they want to dissect the problems for them so...they never have to struggle figuring out the problem itself." Tricia also brought up that she noticed her preservice teachers were sometimes just giving students the answers in their clinicals instead of letting them struggle. Some of that, she believed, was due to a lack of content knowledge on the part of the preservice teachers. She said:

I think some of my [preservice teachers] don't want the kids frustrated and struggling because they themselves probably have felt that, but I don't think they got the benefits out of that process of letting the kid struggle. And when [students] do get frustrated, asking them good questions. They couldn't ask them good 
questions because they didn't have content knowledge to do that. I think that's all correlated together.

The idea of precision came up as well and it seemed that the university professors were including this standard within their mathematics methods courses. Tricia mentioned it more than the other professors and she even tells her preservice teachers, "You are creating a misconception in your own children when you do not write with mathematical preciseness."

\section{Trustworthiness}

Since this is a phenomenological study, it is important to the researcher that she ensures the study accurately reflected the stories of the participants (Miles, Huberman, \& Saldaña, 2014). In order to ensure that the story being told was true, the researcher used triangulation, extensive note taking, and rich descriptions.

Examining three different sources of data; interviews with university professors, surveys with preservice teachers, and documentation from math methods courses, allowed the researcher to use triangulation. First the interviews were transcribed and then coded using open coding. Then the researcher created a construct table (Miles, Huberman, \& Saldaña, 2014) to organize themes found. The survey responses were also organized and coded using open coding. After the open coding, a construct table was created to organize the themes found. The documentation was coded through the use of descriptive coding (Miles, Huberman, \& Saldaña, 2014) and then themes from the interviews and surveys were examined throughout the documentation and highlighted. After all of the coding was completed, the three forms of data were explored together to look for common themes and any commonalities or discrepancies. 
Throughout this process extensive notes were taken and data was organized into a variety of tables. The use of extensive notes helped the researcher to stay focused on the data and the true story that was being told regarding the use of CCSS for mathematics within the math methods courses.

The final way that the researcher maintained trustworthiness in this study is by providing rich descriptions of the data. Throughout the findings section the researcher provided numerous first hand quotes from the participants in hopes of telling their stories.

\section{The Role of the Conceptual Framework}

In this research the conceptual framework was the Common Core Standards for Mathematical Practice, which are meant to convey how the learners should be engaging with mathematics within a classroom (Common Core State Standards Initiative, 2015a). The researcher chose these standards as the conceptual framework since this research focuses on mathematics methods courses where preservice teachers are taught methods for teaching mathematics and given opportunities to practice these methods within classrooms. McCallum (2011) organized the Standards for Mathematical Practice into a diagram (see Figure 1) which includes four main sections: reasoning and explaining, modeling and using tools, seeing structure and generalizing, and overarching habits of mind of a productive mathematical thinker.

Throughout the data analysis this researcher used McCallum's (2011) framework to view the results. The researcher wanted to see how the mathematics methods courses at this university were incorporating those four ideas with their preservice teachers. Thus, the results are viewed through the lens of McCallum's framework but the voices of the preservice teachers and professors are present within the results. 


\section{Summary}

This research looked at two main questions: 1) In what ways do university professors address CCSS for mathematics in their elementary and middle level math methods courses? and 2) How do elementary and middle level majors describe their experiences with CCSS in their math methods courses? When looking at the data, certain themes came up.

For the first research question, it seemed as though the university professors addressed CCSS for mathematics through the use of classroom assignments, preservice teacher expectations, and addressing the language of the standards. When looking at the student surveys, classroom assignments as a theme also seemed to come up, but along with that were some other experiences that the researcher felt worthy of being noted.

It was clear through the responses of teachers and preservice teachers that the CCSS for mathematics were being addressed through the requirement that they were to be posted on all lesson plans and sometimes through other assignments within the courses. It was also consistently noted that collaboration was a key component of these math methods courses and group work was frequently used. Some of the student expectations, such as the idea that preservice teachers needed to teach students perseverance and let them struggle a little with the mathematics, came up with the professors and the preservice teachers.

The mathematical language of the CCSS was not noted by the preservice teachers and was brought up mostly by the elementary math methods professors. Other experiences that were listed by preservice teachers sometimes aligned with what professors mentioned; for example, the idea that there was not enough time in the 
semester was brought up by both preservice teachers and professors. Other experiences that were mentioned included not having discussed the Common Core much within their courses, which caused the researcher to wonder whether the preservice teachers or professors in that situation were being completely honest about the extent to which the CCSS were being addressed in the classroom. This suggests that further study may be needed to discern the full extent of coverage of the CCSS within these courses.

In general, it was clear through this research that there were a variety of ways that university professors were addressing the CCSS for mathematics within their methods courses. The experiences that the students were having in the math methods courses seemed to vary, but in general they seemed to acknowledge that there was some discussion going on regarding the CCSS for mathematics within their math methods courses and the CCSS were expected to be included in lesson plans.

The next chapter will look more closely at these findings and share conclusions the researcher made based on the results. Implications for preservice teachers, professors, and the community will also be explored. Chapter five will end with a conclusion of the research. 


\section{CHAPTER V}

\section{SUMMARY AND CONCLUSIONS}

In the previous chapter the researcher found that university professors teaching elementary and middle level math methods courses in this teacher preparation program were addressing the Common Core State Standards (CCSS) for mathematics through the use of classroom assignments, student expectations, and language. The researcher also found that preservice teachers were describing their experiences with CCSS for mathematics as being addressed in classroom assignments and other experiences within the math methods class. This chapter will summarize the results and share conclusions that the researcher reached based on these results. The researcher will then present implications for this research, limitations, and finally suggestions for future research.

\section{Introduction}

Throughout education the topic of mathematics has seemed to constantly stir up debate as to the best methods of instruction. With the introduction of the Common Core State Standards (CCSS) for mathematics the debate turned to whether or not these rigorous standards that stress conceptual understanding and communication regarding mathematical understanding (Burns, 2013) are best for mathematics students.

Having taught mathematics in the middle level for 13 years, this researcher has experienced firsthand the introduction to a new set of mathematics standards. While the Common Core Standards for Mathematical Practice have many similarities to the 
National Council of Teachers of Mathematics (NCTM) practice standards (Walkowiak, 2015), which had been utilized in many mathematics classrooms prior to the CCSS, these new standards are still being met with trepidation by many. Walkowiak (2015) claims that negative comments from parents regarding their child's mathematics education has increased since the implementation of the Common Core mathematics standards. In the $46^{\text {th }}$ Annual PDK/Gallup Poll, $62 \%$ of parents surveyed opposed having teachers use the CCSS to guide teaching because they feared it would limit the curriculum (Bushaw \& Calderon, 2014). These concerns called for an investigation into teacher preparation to see whether or not preservice teachers were being supported with the new standards and given the resources to be able to effectively teach content supporting these standards.

Using the Common Core Standards for Mathematical Practice as a conceptual framework, this researcher sought to explore how one teacher preparation program was addressing the CCSS within its mathematics methods courses for elementary and middle level preservice teachers. The research questions examined were: 1) In what ways do professors at a large, midwestern university address Common Core standards for mathematics in their elementary and middle level math methods courses? and 2) How do elementary education and middle level education majors at a large, midwestern university describe their experiences with Common Core standards in their math methods courses?

\section{Summary of Results}

In response to the first research question looking at how professors addressed the CCSS within their math methods courses, it was clear in the elementary and middle level methods courses that preservice teachers were asked to provide content standards within their lesson plans but there was not as big a focus on the mathematical practices. Though 
the elementary preservice teachers were not required to provide the mathematical practices used, the practices were still being addressed within the course as points of discussion. The middle level preservice teachers did have to identify the mathematical practices within their lesson plans.

The first mathematical practice, make sense of problems and persevere in solving them, seemed to be strongly addressed within the methods courses with an emphasis from elementary professors to teach the preservice teachers how to let preservice teachers struggle with mathematics. Heather stated, "All our practice standards are embedded in the content." This can be seen through the focus on teaching preservice teachers to persevere, to reason, to model their mathematics, and to be precise with the language.

Both middle level professors brought up the levels of cognitive demands of tasks (Smith \& Stein, 1998) and stressed that they discuss these within their methods courses. They emphasize to the preservice teachers that the tasks within the classroom need to be challenging and Jonathon goes further in saying, "We always talk about justification is a big thing." The middle school professors seemed to focus more on working through challenging problems with preservice teachers and getting them to reason abstractly, make sense of the problems, and model their learning in their clinical experiences.

Only one elementary methods professor provided the researcher with examples of documents that she used in her methods courses. On those documents it was clear that preservice teachers were asked to include a CCSS content standard. Some other expectations listed on her assignments aligned with the Standards for Mathematical Practice, such as "justify," "make connections," and "engage in collaborative learning." While the other two elementary methods professors did not provide the researcher with 
hard copy documents one professor did show the researcher a copy of her final, which asked preservice teachers to list strategies and analyze problems using the CCSS. The third professor also mentioned that her final included questions asking preservice teachers to provide solution strategies that would meet the content standards.

From the professor interviews it was clear that the CCSS were being addressed through classroom assignments and discussions. Professors seemed to have concern with how preservice teachers interpreted the CCSS since the language was more mathematical and with preservice teachers not transferring the practices learned in class to their clinical experiences.

Preservice teacher responses from an online survey showed that overall they felt the CCSS were being used mainly in lesson plans. The idea of collaborative learning also came up frequently and classroom discussions seemed to, for the most part, revolve around ideas in the standards.

There were some responses that seemed to show confusion towards the CCSS, though, as can be seen in this preservice teacher's response of, "This course has not helped me become prepared at all as far as teaching and implementing Common Core standards." In general, the elementary responses showed that the standards were being addressed in assignments, but that preservice teachers wanted more insight into how to support their choice of standard and more time to focus specifically on the standards.

Preservice teacher responses from the middle level math methods courses supported what the professors had said about how they had to list Common Core standards within their lesson plans. Survey responses also claimed that preservice teachers needed to show support for how they would cover that standard in the lesson. 
Collaboration in the course was also mentioned repeatedly and the idea of "challenging problems" came up in many responses.

As with the elementary preservice teacher responses, there was also some concern with the amount of discussion in the course regarding the CCSS. One preservice teacher said, "They ask us to include the standards in our lessons. Other than that we don't get much about Common Core standards." The area of concern with the middle level preservice teachers seemed to be with understanding what the standards mean.

\section{Conclusions}

Using the professor interviews, student surveys, and documents this researcher came up with a few conclusions based on the data. The first conclusion made was that the math methods courses in this study focused mainly on aligning lesson plans to CCSS. Another strand noticed in the data was that the varied agendas of the professors led to a difference in what aspects of Common Core mathematics were being emphasized in each class. Student data were more difficult to link to this since the student responses were anonymous, but based on the professor interviews it was clear that they all focused on different aspects of the CCSS. The final conclusion made by this researcher was that the Common Core content standards were stressed more often than the practice standards. These conclusions will be further examined here with a focus on McCallum's (2011) grouping of the Common Core Standards for Mathematical Practice, which is the conceptual framework of this research.

\section{Focus on Lesson Plans}

The focus of the elementary and middle level math methods courses in this study are to provide preservice teachers with pedagogical content knowledge and to provide 
them with clinical experiences where they can practice their pedagogy. Along with that is the creation of various lesson plans. Since the focus of these courses is to practice teaching and thus includes a lot of lesson planning, it seems obvious that lesson plans would be a focus of these courses.

What did surprise the researcher somewhat, though, was that the CCSS were mainly addressed in these courses as statements to attach on lesson plans. Standards have always been used in lesson plans but this researcher was just thinking that the CCSS would be addressed in a variety of ways and yet the theme of lesson plans just seemed to come up repeatedly with all of the professors mentioning this as how CCSS were addressed in the methods course. When asked to give examples of how their math methods course has prepared them for implementing the CCSS for mathematics, every middle level preservice teacher mentioned lesson plans. This shows that the main way the CCSS are being addressed in the elementary and middle level math methods courses at this teacher preparation program are through lesson plan implementation.

Although the researcher was not provided with student examples of lesson plans to see whether or not the Standards for Mathematical Practice were being implemented, some of the course projects that were provided by the university professors did include lesson analysis. The lessons that were provided to the students did show examples of students reasoning, modeling, seeing structure, and making sense of problems. Thus, all levels of McCallum's grouping were present in the course projects.

In the personal interviews with professors, several also made note of having their preservice teachers examine a more traditional lesson plan versus a more non-traditional lesson plan that would more closely follow the Standards for Mathematical Practice. 
What each of them said was that the preservice teachers had difficulty at first being able to differentiate between the two lesson plans. The university professors did note this, though, and because they were aware that this was difficult for preservice teachers they worked harder at giving them examples of non-traditional lesson plans.

\section{Varied Teacher Agendas}

While there were some similarities in the responses from university professors, it seemed to the researcher that they varied slightly in how they addressed the CCSS in their methods courses. This would make sense as it seems professors at this university are given flexibility in creating their coursework. When asked about whether or not the university or department provided any guidelines on how to address the CCSS within their methods courses each participant stressed there were no guidelines.

One particular example of a varied professor agenda, though, is in the area of language. Four out of the five professors made mention that the CCSS were written by very mathematical people and thus can be a little confusing to dissect for some teachers and preservice teachers. Yet, only two of the professors mentioned language as being addressed within their coursework. Tricia says, "I think part of my job with Common Core standards is getting [preservice teachers] to understand what it is really saying because it's written at such a higher level than what they are used to." The other professors did not mention this aspect of dissecting the language in the CCSS as part of their job description, but if the language is so difficult for preservice teachers they may need this to be part of the course.

Preservice teacher responses showed that not all of the preservice teachers feel like they understand what the CCSS are saying. This is shown in this middle level 
preservice teacher's response, "I feel like we are told to use them [standards] but never told what a lot of them mean." Another middle level methods preservice teacher wrote, "[This class] has not covered them [Common Core standards] very deeply on how to use them effectively at all." These same frustrations were apparent in some of the elementary methods survey responses. An elementary level preservice teacher stated, "I wish I had been given more insight into how to select a Common Core standard and how to support my choice." Another suggested using more course time to specifically discuss the Common Core standards for mathematics because "there are a lot of different categories within the standards and being able to move around and really understand the standards takes time and effort." This is one area that could be addressed within the elementary and middle level methods courses. If preservice teachers struggle with using the content standards then they will more than likely have a hard time with the practice standards as well.

While the researcher was not given any syllabi for the elementary methods courses, she was provided with a syllabus from both middle level methods professors. Comparing those two, it is also clear that there were some variances in the teaching agendas regarding the CCSS. One syllabus mentions in the outline that preservice teachers will be learning about "teaching to the Common Core standards." The other syllabus does not mention this aspect of the course. When comparing assignments among these professors, though, both professors stressed that preservice teachers needed to identify the standards and mathematical practices.

While the assignments showed the middle level professors addressing content standards and practice standards, in his interview Jonathon did state that although it was 
listed on his rubrics he felt that he could have spent more time with the practice standards. He says,

There is a question on there to list the mathematical practices that you think you addressed and some students used the Common Core. Others just made up mathematical practices that weren't Common Core ones. So there was confusion there in terms of that [understanding] staying with them.

It was clear in discussions with the professors that they did discuss their courses with each other and shared ideas. Christine states, "My colleagues support me, I walk down the hall and talk to [colleagues] and others about, you know, I'm trying to do this, what do you think about this." Although there was talk among colleagues it seemed that the courses varied in some ways and what is lacking in one course may be evident in another. Possibly more collaboration among professors could enhance the methods courses.

McCallum's (2011) grouping puts the first practice standard, make sense of problems and persevere in solving them, into the category of overarching habits of mind of a productive mathematical thinker. Based on the results of this study it seems that several preservice teachers are struggling with making sense of the Common Core mathematics standards. This area of McCallum's grouping possibly should be addressed more thoroughly and consistently within the mathematics methods courses at this university.

\section{Practices Not Always Emphasized}

One distinct difference between the elementary and middle level methods courses that was noted by the researcher was the emphasis on content standards versus practice 
standards. The elementary methods professors seemed to focus mainly on content standards whereas the middle level methods professors addressed both content and practice standards. This disparity cannot be seen as well in the preservice teacher responses as they all mentioned the content standards but not specifically the practice standards.

When asked whether she has preservice teachers state the content and practice standards within their lesson plans, Heather said:

Some lessons, not all of them, because I think we spend way more time focusing on the content standards because they have a hard time even making sense of it. They read it and they don't know what it means. Practice standards they read, they think they know what it means.

On the other hand, Christine states that both content standards and practice standards are necessary on her middle level preservice teacher's lesson plans. She says: In all their lesson plans they not only have to identify the mathematical content standards and the mathematical practices that they are addressing in that lesson but they have to tell me when and how [they are addressed], and how that relates to the mathematical goals.

Why are mathematical practices stressed more in middle level math methods courses and not as much in the elementary methods? This is one area that could possibly be explored further as all preservice teachers should be introduced thoroughly to the Common Core content and practice standards. Without a strong background of the mathematical practices present in McCallum's (2011) grouping it may be possible to end 
up leaving out those important practices of reasoning, modeling, and seeing structure within one's lesson plans.

\section{Implications of Addressing CCSS in Methods Courses}

The results of this research provide many key implications for the field of higher education and how they might address Common Core with their preservice teachers. While the main method for addressing the CCSS within the methods courses seemed to be aligning them with lesson plans, there were some variances in how professors addressed the standards and noting these could be beneficial to the field of education. The researcher will specify implications from this research for university professors, preservice teachers, and the community.

\section{Implications for University Professors}

Although the CCSS are not being applied in all 50 states, as of 2015 forty-three states plus the District of Columbia had adopted these standards (Ujifusa, 2015). With the majority of states using CCSS for mathematics, preservice teachers should be prepared to incorporate these standards into their mathematics lessons. A methods course is a place where lesson planning takes center stage and pedagogy is strongly touched upon (Ball, 1990).

In this research it was clear that preservice teachers were being asked to address Common Core content standards within their lessons, but the idea of addressing practice standards was mixed among professors. The Common Core Standards for Mathematical Practice are examples of how teachers should be engaging with mathematics students (Common Core State Standards initiative, 2015a) and thus preservice teachers need to be made fully aware of these methods to involve their learners. 
The language of the standards also came up frequently as an issue with the standards being written in such mathematical language. This language can be confusing to some, especially preservice teachers who have not experienced these standards yet. With the uncertainty of what the standards are saying, it could be difficult for preservice teachers to correctly use them within their lesson plans. Knowing this is an area of concern, university professors could consider integrating more discussion into their methods courses about what the standards are saying.

\section{Implications for Preservice Teachers}

Several of the preservice teachers completing the online survey brought up the issue of time in saying that there was not enough time in the semester to learn everything. Even with time limitations, though, it is necessary for preservice teachers to be aware of the CCSS for mathematics. This study can inform preservice teachers that their lesson plans and assignments will need to encompass the Common Core standards. Through my findings preservice teachers can also know that the standards were written by very mathematical people and thus may be confusing in the language, but that if they put the time in to interpreting the standards it will be beneficial. Heather tells her preservice teachers:

It's not easy and it's not easy for anybody, even teachers who have been teaching for a long time. They read the same document and they are as much at a loss as you are. So, actually, this can be your strength. You can't offer the experience that other teachers have but you can offer the knowledge that they do not have. You could actually help more experienced teachers with less formal training on Common Core. 
If preservice teachers put in the time and effort to truly understand the CCSS for mathematics then it could be helpful to other educators and to them when they enter the classroom.

\section{Implications for the Community}

Although states seem to continue to adopt the CCSS for mathematics, there are still some criticisms about the standards. The $46^{\text {th }}$ Annual PDK/Gallup Poll shows that more than half of the Americans polled oppose the CCSS and have a fear that teachers will lack flexibility in the standards, thus not being able to teach their students in the way that best fits their learning (Bushaw \& Calderon, 2014). This research study can show the community that places of higher education are working to address the CCSS for mathematics and show preservice teachers how they can effectively implement them for their students.

The issues with the language of the standards could also be helpful to the community in showing them that interpretation is important when looking at the standards. Possibly what one person does not like about the standards is just something that is being misinterpreted.

\section{Limitations}

One limitation in this research was time. The researcher wanted to examine specific elementary and middle level methods courses and the length of those courses is one semester, so data had to be collected within that one semester.

Another limitation was preservice teacher data. Preservice teachers were asked to complete an online survey regarding their use of CCSS within their mathematics methods courses. Several of the responses were not complete which makes it difficult to compare. 
If the survey had required that each response be completed that may have made it easier to compare results but the response may have been less.

\section{Future Research}

One way this research could be expanded is by examining more than one institution of higher learning. This research all took place at one midwestern university that has a strong focus on teacher education. Possibly exploring other universities that may not have as strong a focus on teacher education to see whether or not they are addressing the CCSS for mathematics within their methods courses would be something worth further examination.

Another part of this research that could be examined further is the preservice teacher responses. Possibly having a focus group of preservice teachers or just interviewing some of them to gain closer insight into how they describe their experiences with CCSS for mathematics within their methods courses would be helpful to this research.

Making this research longitudinal and following the preservice teachers that responded could be beneficial. By surveying or interviewing the preservice teachers after student teaching the researcher would be able to see whether or not they were implementing the CCSS into their teaching and if they were able to utilize any knowledge they had gained in their methods courses about the CCSS for mathematics. This would be beneficial since several of the preservice teachers in this study had noted that there was not a sufficient amount of time in the methods course to engage students in challenging problems or assess student understanding. 
Finally, when analyzing these results the researcher was able to see the variances among these elementary and middle level methods courses. Another study that could be taken further with this variance is examining higher education institutions and their teacher education departments to see if their methods courses vary as much in content and focus in regards to the CCSS for mathematics.

\section{Conclusion}

The Common Core mathematics standards have been a topic of dispute since they appeared in 2009, but regardless of the disagreements these standards are still prevalent in the majority of mathematics classrooms. Elementary and middle level preservice teachers must be equipped with the knowledge and understanding to incorporate these standards into their mathematics curriculum. One place where preservice teachers can learn how to integrate the standards into their teaching is in their mathematics methods courses.

At the university included in this study elementary and middle level methods courses are introducing the CCSS for mathematics to their preservice teachers and do require that they be added to lesson plans. Preservice teachers are also held up to expectations that they will teach in ways that encompass the ideals in the CCSS for mathematics through the use of varied problem solving techniques and attending to mathematical precision. The language of the CCSS for mathematics was mentioned as something that is addressed within these mathematics methods courses. It did seem as though the content standards were addressed more often than the practice standards in the mathematics methods courses. Finally, while all of the professors shared similar experiences, what was taught in the mathematics methods courses seemed to vary in each 
course with some professors focusing on precision with their students and others focusing on problem solving.

While the mathematics methods at this university do seem to be addressing the CCSS for mathematics within their methods courses, is it enough for the preservice teachers? Will it ever be enough? I leave you with the response of one middle school preservice teacher:

I don't know if you are ever fully prepared to teach standards. I have learned a lot in [this course] and I will definitely carry that with me into the classroom, but education changes so frequently that I do not think anyone is "fully" prepared ever. 


\section{REFERENCES}

Association of Public and Land-Grant Universities. (2011). The common core state standards and teacher preparation: The role of higher education. Retrieved from http://www.aplu.org/projects-and-initiatives/stemeducation/SMTI_Library/APLU-SMTI-Paper-2/file

Ball, D. L. (1990, June). Breaking with experience in learning to teach mathematics: The role of a preservice methods course. For the Learning of Mathematics, 10(2), 1016.

Baron, K. (2014, January 12). Patchwork approach to common core in teacher preparation programs. Retrieved from http://edsource.org/2014/scattershot-pathto-common-core-at-teacher-preparation-programs/54468

Biddix, J. P. (2009, July 17). Qualitative coding and analysis. Retrieved from https://researchrundowns.wordpress.com/qual/qualitative-coding-analysis/

Blackburn. B.R. (2012). The beginner's guide to understanding rigor. Retrieved from http://www.barbarablackburnonline.com/rigor/

Blosveren, K., Liben, M. \& DeWitt, S. (2014, November/December). Common core: The challenge and the opportunity. Techniques: Connecting Education and Careers, 89(8), 14-18.

Bogdan, R. C., \& Biklen, S. K. (1998). Qualitative research for education: An introduction to theories and methods ( $3^{\text {rd }}$ ed.). Boston, Massachusetts: Allyn and 
Bacon.

Bomer, R., \& Maloch, B. (2011). Relating policy to research and practice: The Common Core standards. Language Arts, 89(1), 38-43.

Bourke, B. (2014). Positionality: Reflecting on the research process. The Qualitative Report, 19, 1-9.

Burns, M. (2013 January). Go figure: Math and the common core. Educational Leadership, 70(4), 42-46.

Burton, M., Daane, C. J., \& Giesen, J. (2008 May). Infusing mathematics content into a methods course: Impacting content knowledge for teaching. Issues in the Undergraduate Mathematics Preparation of School Teachers, 1. Retrieved from http://files.eric.ed.gov/fulltext/EJ835496.pdf

Bushaw, W. J., \& Calderon, V. J. (2014). Try it again, Uncle Sam. Kappan, 96(1), 9-20. Center for Public Education. (2014, April). Understanding the common core. Education Digest, 79(8), 16-21.

Cogan, L., Schmidt, W., \& Houang, R. (2013). Implementing the common core state standards for mathematics: What parents know and support. The Education Policy Center. Retrieved from http://education.msu.edu/epc/publications/documents/ WP34ImplementingtheCommonCoreStateStandardsforMathematics WhatParents KnowandSupport.pdf

Common Core State Standards Initiative. (2015a). Standards for Mathematical Practice. Retrieved from http://www.corestandards.org/Math/Practice

Common Core State Standards Initiative. (2015b). Read the standards. Retrieved 
from http://www.corestandards.org/read-the-standards/

Common Core State Standards Initiative. (2015c). Mathematics standards. Retrieved from http://www.corestandards.org/Math/

Common Core State Standards Initiative. (2016). Development process. Retrieved from http://www.corestandards.org/about-the-standards/development-process/

Cooper, J. M., \& Alvarado, A. (2006). Preparation, recruitment, and retention of teachers. Paris, France: UNESCO. Retrieved from http://www.unesco.org/iiep/PDF/Edpol5.pdf

Creswell, J. W. (2013). Qualitative inquiry and research design: Choosing among five approaches. Thousand Oaks, California: Sage.

DeNisco, A. (2016, August). Five years in, results paint complex picture of common core. District Administration. Retrieved from http://www.districtadministration.com/article/five-years-results-paint-complexpicture-common-core

Denscombe, M. (2003). The good research guide ( $2^{\text {nd }}$ ed.). Berkshire, England: Open University Press.

Dunkle, C. A. (2012). Leading the common core state standards: From common sense to common practice. Thousand Oaks, California: Corwin.

Editorial Projects in Education (2013). Findings from a national survey of teacher perspectives on the common core. Retrieved from http://www.edweek.org/media/epe_survey_teacher_perspctives_common_core_2 013.pdf

Education Week Research Center (2014). From adoption to practice: Teacher 
perspectives on the common core. Retrieved from

http://www.edweek.org/media/ewrc_teacherscommoncore_2014.pdf

Eilers, L. H., \& D’Amico, M. (2012). Essential leadership elements in implementing Common Core state standards. Delta Kappa Gamma Bulletin, 78(4), 46-50.

Ellis, M. W., \& Berry III, R. Q. (2005). The paradigm shift in mathematics education: Explanations and implications of reforming conceptions of teaching and learning. The Mathematics Educator, 15(1), 7-17.

Fairbanks, A. M. (2015, January 8). Will test-based teacher evaluations derail the common core? The Hechinger Report. Retrieved from http://hechingerreport.org/will-test-based-teacher-evaluations-derail-commoncore/

Flick, U. (2004). Constructivism. In U. Flick, E. von Kardorff, \& I. Steinke (Eds.), $A$ companion to qualitative research (pp. 88-94). Thousand Oaks, California: Sage.

Foster, A. (2014, August 25). PDK/Gallup poll: When answers mean more questions. Retrived from http://www.learningfirst.org/pdkgallup-poll-when-answers-meanmore-questions

Gojak, L.M. (2013, February 5). What's all this talk about rigor? Retrieved from http://www.nctm.org/News-and-Calendar/Messages-from-thePresident/Archive/Linda-M_-Gojak/What_s-All-This-Talk-about-Rigor_/

Golafshani, N. (2003 December). Understanding reliability and validity in qualitative research. The Qualitative Report, 8(4), 597-607. Retrieved from http://www.nova.edu/ssss/QR/QR8-4/golafshani.pdf 
Graeber, A. O. (1999). Forms of knowing mathematics: What preservice teachers should learn. Educational Studies in Mathematics, 38(1-3), 189-208.

Greenberg, J., \& Walsh, K. (2008). No common denominator: The preparation of elementary teachers in mathematics by America's education schools. National Council on Teacher Quality. Retrieved from http://www.nctq.org/dmsView/No_Common_Denominator_Executive_Summary pdf

Greenberg, J., McKee, A., \& Walsh, K. (2013). Teacher prep review: A review of the nation's teacher preparation programs. National Council on Teacher Quality. Retrieved from http://www.nctq.org/dmsStage/Teacher_Prep_Review_2013_Report

Guba, E. G., \& Lincoln, Y. S. (1994). Competing paradigms in qualitative research. In N.K. Denzin \& Y.S. Lincoln (Eds.), Handbook of qualitative research (pp.105117). Thousand Oaks, California: Sage.

Hatch, J. A. (2002). Doing qualitative research in education settings. Albany, New York: State University of New York Press.

Hill, H.C., Schilling, S.G., \& Ball, D. L. (2004, September). Developing measures of teachers' mathematics knowledge for teaching. The Elementary School Journal, 105(1), 11-30.

Hill, D., Stumbo, C., Paliokas, K., Hansen, D., \& McWalters, P. (2010). State policy implications of the model core teaching standards (InTASC draft discussion document). Washington, D.C.: Council of Chief State School Officers. Retrieved from http://www.ccsso.org/Documents/2010/State_Policy_Implications_ 
Model_Core_Teaching_DRAFT_DISCUSSION_DOCUMENT_2010.pdf

Hitzler, R., \& Eberle, T. S. (2004). Phenomenological life-world analysis. In U. Flick, E. von Kardorff, \& I. Steinke (Eds.), A companion to qualitative research (pp. 6771). Thousand Oaks, California: Sage.

Hudelson, P. M. (2004). Culture and quality: An anthropological perspective. International Journal for Quality in Health Care, 16(5), 345-346.

Hull, T. H., Miles, R. H., \& Balka, D. S. (2012). The common core mathematics standards: Transforming practice through team leadership. Thousand Oaks, California: Corwin Press.

Ingersoll, R., Merrill, L., \& May, H. (2012). Retaining teachers: How preparation matters. Educational Leadership. Retrieved from http://www.gse.upenn.edu/pdf/rmi/EL-May2012.pdf

Jones, A. G., \& King, J. E. (2012). The common core state standards: A vital tool for higher education. Change: The Magazine of Higher Learning, 44(6), 37-43. doi: $10.1080 / 00091383.2012 .706529$

Klein, D. (2003). A brief history of American K-12 mathematics education in the $20^{\text {th }}$ century. Retrieved from http://www.csun.edu/ vcmth00m/AHistory.html

Klein, D. (2007). A quarter century of US 'math wars' and political partisanship. Retrieved from http://www.csun.edu/ vcmth00m/bshm.html

Kober, N., \& Rentner, D. S. (2011). Common core state standards: Progress and challenges in school districts' implementation. Center on Education Policy, Washington, D.C. Retrieved from http://www.cepdc.org/displayDocument.cfm?DocumentID=374 
Kober, N., \& Rentner, D. S. (2012). Year two of implementing the common core state standards: States' progress and challenges. Center on Education Policy, Washington, D.C. Retrieved from http://www.cepdc.org/displayDocument.cfm?DocumentID=391

Lincoln, Y. S., \& Guba, E. G. (1985). Naturalistic Inquiry. Newbury Park, California: Sage Publications.

Lodico, M., Spaulding, D., \& Voegtle, K. (2010). Methods in educational research: From theory to practice ( $2^{\text {nd }}$ ed.). San Francisco, California: Jossey-Bass.

Ma, L. (1999). Knowing and teaching elementary mathematics: Teachers' understanding of fundamental mathematics in China and the United States. Mahwah, New Jersey: Lawrence Erlbaum Associates.

Marx, W. (1970). The life-world and the particular sub-worlds. In M. Natanson (Ed.), Phenomenology and social reality: Essays in memory of Alfred Schutz (pp. 62-72). The Hague, Netherlands: Martinus Nijhoff.

McCallum, B. (2011, March 10). Structuring the mathematical practices. Retrieved from http://commoncoretools.me/2011/03/10/structuring-the-mathematicalpractices/

McGuinn, P. (2015, September). Complicated politics to the core: The bumpy implementation of the Common Core and its assessments has a thorny knot of political alliances and adversaries. Kappan, 97(1), 14-19.

Mehra, B. (2002, March). Bias in qualitative research: Voices from an online classroom. The Qualitative Report, 7(1). Retrieved from http://www.nova.edu/ssss/QR/QR71/mehra.html 
Merriam, S. B. (1998). Qualitative research and case study applications in education. San Francisco, CA: Wiley \& Sons.

Merriam, S. B., Ntseane, G., Lee, M., Kee, Y., Johnson-Bailey, J., \& Muhamad, M. (2001, September). Power and positionality: negotiating insider/outsider status within and across cultures. International Journal of Lifelong Education, 20(5), 405 $-416$.

Miles, M. B., Huberman, A. M., \& Saldaña, J. (2014). Qualitative data analysis: A methods sourcebook ( $3^{\text {rd }}$ ed.). Thousand Oaks, California: Sage.

Natanson, M. (1970). Alfred Schutz on social reality and social science. In M. Natanson (Ed.), Phenomenology and social reality: Essays in memory of Alfred Schutz (pp. 101-121). The Hague, Netherlands: Martinus Nijhoff.

National Council of Teachers of Mathematics (2000). Principles and Standards for School Mathematics. Reston, VA: NCTM.

Nelson, L.A. (2013, May 3). The common core on campus. Inside Higher Ed. Retrieved from https:/www.insidehighered.com/news/2013/05/03/common-corecurriculum-k-12-could-have-far-reaching-effects-higher-education

O'Brien, A. (2013, October 16). Educator preparation and the common core: A voice from the field. Learning First Alliance. Retrieved from http://www.learningfirst.org/educator-preparation-and-common-core-voice-field

Pae, H., Freeman, G. G., \& Wash, P. D. (2014). Preservice teacher preparation for common core standards and assessments: A pilot study. AILACTE Journal, XI(1), 73-89.

Paliokas, K. (2014, May). Preparing teachers for the common core: Aligning preparation 
program curricula. Center on Great Teachers and Leaders. Retrieved from http://www.gtlcenter.org/sites/default/files/Teacher_Preparation_Common_Core. pdf

Peshkin, A. (1988, October). In search of subjectivity - One's own. Educational Researcher, 17(7), 17-21.

Porter, A., McMaken, J., Hwang, J., \& Yang, R. (2011). Common core standards: The new U.S. intended curriculum. Educational Researcher, 40(3), 103-116.

Quinn, R. J. (1997). Effects of mathematics methods courses on the mathematical attitudes and content knowledge of preservice teachers. The Journal of Educational Research, 91(2), 108. Retrieved from http://search.ebscohost.com

Reese, W. J. (2001). The origins of progressive education. History of Education Quarterly, 41(1), 1-24.

Reese, W. J. (2013). In search of American progressives and teachers. History of Education, 42(3), 320-334.

Rich, M. (2015, October 28). Nationwide test shows dip in students' math abilities. The New York Times. Retrieved from http://www.nytimes.com/2015/10/28/us/nationwide-test-shows-dip-in-studentsmath-abilities.html?WT.mc_id=SmartBriefs-Newsletter\&WT.mc_ev=click\&_r=0

Rust, T. (2012). Common core standards. Technology \& Engineering Teacher, 72(3), $32-36$.

Saldaña, J. (2009). The coding manual for qualitative researchers. Thousand Oaks, California: Sage Publications.

Sawchuk, S. (2012, April 25). Many teachers not ready for the common core. 
Education Week, 31, S12-17.

Sawchuk, S. (2014, April 23). Standards pose teacher-prep challenge. Education Week, 33(29), S14-16. Retrieved from http://www.edweek.org/ew/articles/2014/04/23/29cc-preparation.h33.html

Schmidt, W. (2015, October 1). Mathematics instruction and the Common Core: Where do we go from here? [Webinar]. In REL Mid-Atlantic Webinar. Retrieved from http://files.eric.ed.gov/fulltext/ED562600.pdf

Schoenfeld, A. H. (2004). The math wars. Educational Policy, 18(1), 253-286.

Schwartze, M., \& Hatch, D. (2015, May). Common core standards and interdisciplinary instruction: Do common core standards help or hinder interdisciplinary instruction. AMLE Magazine, 2(9), 22-23.

Shenton, A. K. (2004). Strategies for ensuring trustworthiness in qualitative research projects. Education for Information, 22, 63-75.

Shulman, L. S. (1987 February). Knowledge and teaching: Foundations of the new reform. Harvard Educational Review, 57(1). Retrieved from http://people.ucsc.edu/ ktellez/shulman.pdf

Skemp, R. R. (1976). Relational understanding and instrumental understanding. Mathematics Teaching, 77, 20-26. Retrieved from http://static1.squarespace.com/static/53b6662ae4b00ce9a7c30e76/t/5548a95ae4b0 3cee0387aef9/1430825306203/Mona+Rosseland+12.11.14+Vedlegg.pdf

Smith, M.S. \& Stein, M. K. (1998, February). Selecting and creating mathematical tasks: From research to practice. Mathematics Teaching in the Middle School, 3(5), 344350. 
Smith, M. E., Swars, S. L., Smith, S. Z., Hart, L. C., \& Haardorfer, R. (2012). Effects of an additional mathematics content course on elementary teachers' mathematical beliefs and knowledge for teaching. Action in Teacher Education, 34(4), 336348.

Superfine, A. C., \& Li, W. (2014). Exploring the mathematical knowledge needed for teaching teachers. Journal of Teacher Education, 65(4), 303-314.

Tooke, D. J. (1997, Sep - Oct). Middle school math teachers: What do they need from preservice programs? The Clearing House, 71(1), 51-52.

Ujifusa, A. (2015, June 30). A ‘Common-Core math' problem: How many states have adopted the standards? [Web log post]. Retrieved from http://blogs.edweek.org/edweek/state_edwatch/2015/06/a_common_core_math_p roblem_how_many_states_have_adopted_the_standards.html

VanTassel-Baska, J. (2015 January). Arguments for and against the common Corestate standards. Gifted Child Today, 38(1), 60-62. doi: 10.1177/1076217514556535

Walkowiak, T. A. (2015, October). Information is a common core dish best served first. Kappan, 97(2), 62-67

Watt, D. (2007, March). On becoming a qualitative researcher: The value of reflexivity. The Qualitative Report, 12(1), 82-101.

Weiss, S. (2015). Room for improvement. State Legislatures, 41(3), 26-30.

Western Interstate Commission for Higher Education (WICHE) (2011 June). The common core state standards: Implications for higher education in the west. Retrieved from http://www.wiche.edu/info/publications/PICommonCoreStateStandards.pdf 
Wilkins, J. L. M., \& Brand, B. R. (2004 May). Change in preservice teachers' beliefs: An evaluation of a mathematics methods course. School Science and Mathematics, 104(5), 226-232.

Zhang, S. (2014). New teachers' implementation of the common core state standards. Action in Teacher Education, 36, 465-479. doi:

$10.1080 / 01626620.2014 .977745$ 


\section{APPENDIX A \\ FACULTY RECRUITMENT LETTER}

December 9, 2015

Dear Professor,

I, Michelle Schwartze, am a doctoral student in the School of Teaching and Learning at Illinois State University. I am conducting a research study for my dissertation under the direction of Dr. Douglas Hatch examining the math methods courses at XXX University and how the Common Core standards for mathematics have been incorporated within the curriculum. My questions of interest are: 1 . In what ways do university professors address Common Core standards for mathematics in their math methods courses? 2. How do elementary and middle level education majors describe their experiences with Common Core standards in their math methods courses?

Participation is voluntary and you may drop out of the study at any time with no penalty. The study will involve an hour-long one-on-one interview with me. During the interview, you will be asked questions about the math methods courses you teach and how you incorporate Common Core standards for mathematics into those courses. All interviews will be audio-recorded in order to ensure accurate transcriptions. No identifiers will be used on the audio recording and the recording will be deleted within three years of completion of this dissertation. You will have the right to choose to skip any of the questions and the information provided will be kept strictly confidential. The interview will be carried out at a place of your choosing. Along with the interview, I may request documents that relate to your teaching of the Common Core within your methods courses such as a copy of your class syllabus.

The results from the study will be presented in a dissertation. Data from the interviews may also be included in research presentations or publications. Benefits of participating in this study would be that the results may help universities to examine their own math methods courses and how they are incorporating Common Core standards within their curricula. The primary risk for this type of research is loss of confidentiality. To address this, pseudonyms will be used in the presentation of the results in place of participant names and the name of the university will be kept confidential. This will ensure confidentiality. All data will also be stored in a locked computer or file cabinet.

If you have any questions concerning this research study, please call me at XXX or contact Dr. Douglas Hatch at XXX. 
Sincerely,

Michelle Schwartze

Participant Signature

Date

If you have any questions about your rights as a subject/participant in this research, or if you feel you have been placed at risk, you may contact the Research Ethics and

Compliance Office at Illinois State University at 309-438-2529. 


\section{APPENDIX B}

\section{TELEPHONE SCRIPT FOR FACULTY RECRUITMENT}

My name is Michelle Schwartze, and I am a doctoral student at Illinois State University in the Teaching and Learning program. Currently I am working on my dissertation. The purpose of my dissertation, An Examination of How One University is Preparing Elementary and Middle Level Education Majors for Common Core Mathematics, is to determine the degree to which XXX University is incorporating Common Core standards within their math methods courses. This is an exploratory, phenomenological study that will be looking at whether or not math methods courses are being affected by the Common Core standards and in what ways. Names of participants will not be given in this dissertation and the university will be referred to as a large, midwestern university.

I will be conducting face-to-face interviews that should last no longer than an hour. There are nine questions that ask about your familiarity with the Common Core standards and how you address them within your math methods courses. I will also ask if you have any documents, such as a syllabus or course project, that you would be willing to share with me for the purpose of this study.

Do you have any questions or concerns? Now that you have a basic understanding of the study, do you think you would be willing to participate in an interview?

If No: Thank you very much for your time.

If Yes: Can we schedule a time to meet for the interview. 


\section{APPENDIX C \\ INTERVIEW QUESTIONS FOR FACULTY}

1. How long have you taught the Math Methods course here or at another university?

2. What types of math courses are preservice teachers required to take at this university?

3. How familiar would you say you are with the Common Core math standards?

4. Since Common Core was adapted in your state, have changes been made to the math methods course you teach and, if so, what specific examples do you have of these changes?

5. Hull, Miles, and Balka (2012) claim that when teaching Common Core you must include challenging problems, student collaborative groups, interactive discourse, and adequate time. Do you incorporate any of these within your math methods courses?

6. How do you specifically address the $\mathrm{CC}$ standards or standards for mathematical practice in the math methods course?

7. In what ways, if any, does the university or department provide you with guidelines on how to address CC math standards within the methods course?

8. Has your mindset changed, based on the Common Core, in the way you prepare future educators to successfully teach math? Explain. 
9. Do you have a syllabus or examples of projects that you could share with me? 


\section{APPENDIX D}

\section{RECRUITMENT LETTER FOR PRESERVICE TEACHERS}

December 8, 2015

Dear Student,

I, Michelle Schwartze, am a doctoral student in the School of Teaching and Learning at Illinois State University. I am conducting a research study for my dissertation under the direction of Dr. Douglas Hatch examining math methods courses at XXX University and how the Common Core standards for mathematics have been incorporated within the curriculum. My questions of interest are: 1 . In what ways do university professors address Common Core standards for mathematics in their math methods courses? 2. How do elementary and middle level education majors describe their experiences with Common Core standards in their math methods courses?

Participation is voluntary and you may drop out of the study at any time with no penalty. The study will involve you completing an online survey about the math methods course you are currently enrolled in and how you have seen Common Core standards for mathematics incorporated within that course. The survey should take between 10 and 15 minutes to complete. You will be able to skip questions on the survey if you are unsure of an answer.

The results from the study will be presented in a dissertation. The findings from this study will help universities to examine their own math methods courses and how they are incorporating Common Core standards within their curricula. The primary risk for this type of research is loss of confidentiality. To address this, the name of the university will be kept confidential within the paper. Students will be unidentifiable, as the online survey will not ask for a name. All data collected will be stored in a locked computer or file cabinet.

If you have any questions concerning this research study, please call me at XXX or contact Dr. Douglas Hatch at XXX.

Sincerely,

Michelle Schwartze 


\section{APPENDIX E \\ ONLINE SURVEY FOR PRETEACHER CANDIDATES}

1. How familiar are you with the CC math standards?

2. Give examples of how your math methods course has prepared you for implementing $\mathrm{CC}$ standards in teaching math.

3. Hull, Miles, and Balka (2012) claim that when teaching Common Core you must include challenging problems, student collaborative groups, interactive discourse, and adequate time. Do you feel like you experienced any of these within your math methods course? Explain.

4. Do you feel ready to teach math using CC standards? Explain why or why not.

5. What else could be done in your math methods courses to prepare you for CC?

6. How many years have you been at this institution?

7. What is your major?

8. Have you taken other math methods courses? If so, how many? 


\section{APPENDIX F}

\section{OPEN CODING}

RQ 1: In what ways do university professors address CCSS for mathematics in their math methods courses? (ELEMENTARY)

\begin{tabular}{|c|c|c|}
\hline Open code & Properties & $\begin{array}{l}\text { Example of participants' } \\
\text { words }\end{array}$ \\
\hline Within lesson plans & $\begin{array}{l}\text { Content and practice standards } \\
\text { listed }\end{array}$ & $\begin{array}{l}\text { "We spend way more time } \\
\text { focusing on the content } \\
\text { standards because content } \\
\text { standards they have a hard } \\
\text { time even making sense of it, } \\
\text { they read it and they don't } \\
\text { know what it means" }\end{array}$ \\
\hline Classroom discussions & $\begin{array}{l}\text { Talk about CCSS is a } \\
\text { benchmark } \\
\text { Allow kids to struggle with } \\
\text { their math knowledge } \\
\text { Important to write meaningful } \\
\text { tasks }\end{array}$ & $\begin{array}{l}\text { "It doesn't narrow the focus" } \\
\text { "All our practice standards } \\
\text { type of discussions are } \\
\text { embedded in the content" } \\
\text { "you can't really have a good } \\
\text { class if you don't have good } \\
\text { tasks" } \\
\text { "I don't, I guess, lecture on it, } \\
\text { I don't talk about the practice } \\
\text { standards in a vacuum" }\end{array}$ \\
\hline Expectations & $\begin{array}{l}\text { Follow the standards in what } \\
\text { they do } \\
\text { Asking questions to get them } \\
\text { to think about solving } \\
\text { problems in another way } \\
\text { Research shows kids are } \\
\text { capable of learning this } \\
\text { Get kids to talk about learning } \\
\text { Stop doing so much direct } \\
\text { instruction }\end{array}$ & $\begin{array}{l}\text { "Write mathematically in the } \\
\text { classroom" } \\
\text { "It's most beneficial for these } \\
\text { kids" } \\
\text { "How about we teach for } \\
\text { understanding versus teaching } \\
\text { it for rote memorization" } \\
\text { "[CCSS] gives us more reason } \\
\text { for teacher to know and } \\
\text { provide logic for it" } \\
\text { "Emphasize interaction } \\
\text { between the kids, encourage } \\
\text { dialogue, collaboration } \\
\text { between the kids" }\end{array}$ \\
\hline
\end{tabular}




\begin{tabular}{|c|c|c|}
\hline Classroom assignments & $\begin{array}{l}\text { Match questions on Everyday } \\
\text { Math assessments with CCSS } \\
\text { Open response questions } \\
\text { Try to distinguish between } \\
\text { traditional curriculum and } \\
\text { research based curriculum } \\
\text { Reading assignment with } \\
\text { practice standards and } \\
\text { problem solving } \\
\text { Brainstorm strategies } \\
\text { Watch videos }\end{array}$ & $\begin{array}{l}\text { "Sometimes we present } \\
\text { solution strategies and we talk } \\
\text { about did anyone have a } \\
\text { different solution strategy" } \\
\text { "It struck me odd that they } \\
\text { couldn't tell, initially could } \\
\text { not tell the difference between } \\
\text { the two" } \\
\text { "Without the experience there } \\
\text { are certain things they just } \\
\text { can't do, but before I thought } \\
\text { they were just being lazy" } \\
\text { "It remains exactly the same in } \\
\text { terms of what we teach but I } \\
\text { think we are making it more } \\
\text { explicit because we can pull } \\
\text { out" } \\
\text { "we didn't change a lot of } \\
\text { what we were actually } \\
\text { teaching because of the fact } \\
\text { that what we were teaching } \\
\text { came from the research that } \\
\text { common core came from" } \\
\text { "I'll just give them these } \\
\text { mental math problems and } \\
\text { they'll come up with as many } \\
\text { strategies as they possibly can } \\
\text { and then we'll go through and } \\
\text { we'll look at their strategies" } \\
\text { "We'll say what standards of } \\
\text { practice was this teacher } \\
\text { addressing in this clip" }\end{array}$ \\
\hline Dissecting the language & $\begin{array}{l}\text { Talk about how the words are } \\
\text { often misused } \\
\text { Misconceptions from } \\
\text { practicing teachers } \\
\text { Language is very } \\
\text { mathematical }\end{array}$ & $\begin{array}{l}\text { "Often our students don't } \\
\text { understand the language in the } \\
\text { common core standards" } \\
\text { "Part of my job with common } \\
\text { core standards is getting kids } \\
\text { to understand what it is really } \\
\text { saying" } \\
\text { "The phrase standard } \\
\text { algorithm is defined to be any } \\
\text { algorithm that is } \\
\text { generalizable" } \\
\text { "Common core doesn't mean } \\
\text { you're only restricted to this } \\
\text { curriculum" } \\
\text { "I have them read and what do } \\
\text { you think that means, } \\
\text { oftentimes they don't, they } \\
\text { can't really articulate" }\end{array}$ \\
\hline
\end{tabular}




\begin{tabular}{|l|l|l|}
\hline Classroom assessments & $\begin{array}{l}\text { Justify which strategy would } \\
\text { be used } \\
\text { Match solution strategies to } \\
\text { standards }\end{array}$ & $\begin{array}{l}\text { "Now when I write the test, } \\
\text { instead of saying which } \\
\text { strategy is most } \\
\text { mathematically sophisticated I } \\
\text { would say which strategy } \\
\text { meets the standards" }\end{array}$ \\
\hline
\end{tabular}

RQ 1: In what ways do university professors address CCSS for mathematics in their math methods courses? (MIDDLE LEVEL)

\begin{tabular}{|c|c|c|}
\hline Open code & Properties & $\begin{array}{l}\text { Example of participants' } \\
\text { words }\end{array}$ \\
\hline Within lesson plans & $\begin{array}{l}\text { List content standards and } \\
\text { practice standards }\end{array}$ & $\begin{array}{l}\text { "We try to do practices as } \\
\text { well, I probably was not as } \\
\text { strong in that this semester } \\
\text { because I think the hard part is } \\
\text { if you look at the way I teach } \\
\text { and what we do cover those } \\
\text { things but to make them } \\
\text { specifically point out which } \\
\text { ones they were not so much" } \\
\text { "In all their lesson plans they } \\
\text { not only have to identify the } \\
\text { mathematical content } \\
\text { standards and the } \\
\text { mathematical practices that } \\
\text { they are addressing in that } \\
\text { lesson but they have to tell me } \\
\text { when and how, and how that } \\
\text { relates to the mathematical } \\
\text { goals. }\end{array}$ \\
\hline Classroom discussions & $\begin{array}{l}\text { Cognitive demands of tasks } \\
\text { Discourse } \\
\text { Justification } \\
\text { Talk moves }\end{array}$ & $\begin{array}{l}\text { "We analyze different tasks" } \\
\text { "We are always talking back } \\
\text { and forth about things" } \\
\text { "I debrief with my students } \\
\text { sometimes we'll talk about, } \\
\text { you know, what do you think, } \\
\text { did you keep the cognitive } \\
\text { demand of the task or at some } \\
\text { point was it reduced for a } \\
\text { variety of tasks." } \\
\text { "It's important to figure out } \\
\text { what the kids know and to do } \\
\text { so to get them talking and so } \\
\text { we talk about talk moves" }\end{array}$ \\
\hline Expectations & $\begin{array}{l}\text { Giving students time to } \\
\text { struggle } \\
\text { Getting students to practice } \\
\text { what they learn in their } \\
\text { clinicals }\end{array}$ & $\begin{array}{l}\text { "Sometimes students will give } \\
\text { them the answer and they just } \\
\text { don't know what to do with it" } \\
\text { "They have a tendency to } \\
\text { underestimate what children }\end{array}$ \\
\hline
\end{tabular}




\begin{tabular}{|c|c|c|}
\hline & $\begin{array}{l}\text { Collaboration } \\
\text { Reason through things } \\
\text { Not only direct instruction }\end{array}$ & $\begin{array}{l}\text { know" } \\
\text { "We want them to actually } \\
\text { reason through things so we } \\
\text { can emphasize the three } \\
\text { competencies: conceptual } \\
\text { understanding, procedural } \\
\text { skill, and problem solving" } \\
\text { "Always follow your students' } \\
\text { thinking" } \\
\text { "I am overemphasizing these } \\
\text { so that there's more of a } \\
\text { mixture rather than only direct } \\
\text { instruction, cause it's more } \\
\text { than that" }\end{array}$ \\
\hline Classroom assignments & $\begin{array}{l}\text { Connecting to CCSS } \\
\text { Challenging tasks } \\
\text { Write assessment items }\end{array}$ & $\begin{array}{l}\text { "We used to in the methods } \\
\text { course do textbook analysis } \\
\text { and talk about how you plan } \\
\text { things but now it's kind of up } \\
\text { in the air because it doesn't } \\
\text { seem like they are guaranteed } \\
\text { any textbooks of any sort" } \\
\text { "I do encourage teaching } \\
\text { mathematics through } \\
\text { problems, through context" }\end{array}$ \\
\hline Dissecting the language & Interpreting the standards & $\begin{array}{l}\text { "The hard part with standards } \\
\text { are we could read the same } \\
\text { standards and my expectations } \\
\text { on what the standards mean } \\
\text { and what you think it means } \\
\text { could be two different things" }\end{array}$ \\
\hline Classroom assessments & Reflections & $\begin{array}{l}\text { "There's an assessment piece } \\
\text { like how will you assess } \\
\text { whether or not your students } \\
\text { now understand what you } \\
\text { intended for them to } \\
\text { understand from your } \\
\text { mathematical goals" }\end{array}$ \\
\hline
\end{tabular}

RQ2: How do elementary and middle level majors describe their experiences with CCSS in their math methods courses? (ELEMENTARY)

\begin{tabular}{|l|l|l|}
\hline Open code & Properties & $\begin{array}{l}\text { Example of participants' } \\
\text { words }\end{array}$ \\
\hline Lesson plans & $\begin{array}{l}\text { Had to list standards for each } \\
\text { lesson plan }\end{array}$ & $\begin{array}{l}\text { "Connecting my lesson plans } \\
\text { to the common core" }\end{array}$ \\
\hline
\end{tabular}




\begin{tabular}{|c|c|c|}
\hline & & $\begin{array}{l}\text { "We have used the } \\
\text { Mathematical Common Core } \\
\text { Standards to write lesson } \\
\text { plans" } \\
\text { "For each lesson plan we were } \\
\text { required to connect them back } \\
\text { to standards" }\end{array}$ \\
\hline Varying types of instruction & $\begin{array}{l}\text { Thought of different types of } \\
\text { instruction to meet standards }\end{array}$ & $\begin{array}{l}\text { "think about ways to use } \\
\text { different types of instruction } \\
\text { within our future classrooms" }\end{array}$ \\
\hline Confusing & $\begin{array}{l}\text { Not helpful } \\
\text { Poorly planned }\end{array}$ & $\begin{array}{l}\text { "This course has not helped } \\
\text { me become prepared at all as } \\
\text { far as teaching and } \\
\text { implementing CC standards." } \\
\text { "I was not given time to do it } \\
\text { myself or necessarily taught } \\
\text { how to do it well with my } \\
\text { students" } \\
\text { "We have only touched upon } \\
\text { the common core standards } \\
\text { about twice" } \\
\text { "My professor does not } \\
\text { prepare us at all or relate any } \\
\text { of the course material to the } \\
\text { common core standards" }\end{array}$ \\
\hline Collaboration & Through clinicals & $\begin{array}{l}\text { "We have also taught students } \\
\text { in collaborative groups } \\
\text { through the clinical experience } \\
\text { this course offers" }\end{array}$ \\
\hline Problem solving & $\begin{array}{l}\text { Challenging problems } \\
\text { Classroom discussions }\end{array}$ & $\begin{array}{l}\text { "We have worked hard to } \\
\text { examine multiple forms of } \\
\text { problems and multiple ways to } \\
\text { solve those problems in order } \\
\text { to fully be able to help our } \\
\text { students" }\end{array}$ \\
\hline
\end{tabular}

RQ2: How do elementary and middle level majors describe their experiences with CCSS in their math methods courses? (MIDDLE LEVEL)

\begin{tabular}{|l|l|l|}
\hline Open code & Properties & $\begin{array}{l}\text { Example of participants' } \\
\text { words }\end{array}$ \\
\hline Lesson plans & List standards for each lesson & $\begin{array}{l}\text { "We had to specifically } \\
\text { reference the common core } \\
\text { standards when creating lesson } \\
\text { plans and had to support how } \\
\text { we were going to cover that }\end{array}$ \\
\hline
\end{tabular}




\begin{tabular}{|c|c|c|}
\hline & & $\begin{array}{l}\text { particular topic in our lesson" } \\
\text { "Everything we do is based off } \\
\text { or involves the CCSS" }\end{array}$ \\
\hline Class discussions & How to address standards & $\begin{array}{l}\text { "Many class discussions } \\
\text { focused on how standards } \\
\text { could be addressed" }\end{array}$ \\
\hline Lacking & $\begin{array}{l}\text { Not much depth } \\
\text { No writing of problems } \\
\text { Only focused on one grade } \\
\text { level }\end{array}$ & $\begin{array}{l}\text { "It has not covered them very } \\
\text { deeply on how to use them } \\
\text { effectively at all" } \\
\text { "They ask us to include } \\
\text { standards in our lessons. Other } \\
\text { than that we don't get much } \\
\text { about common core standards" } \\
\text { "Nobody ever teaches you } \\
\text { how to write a problem they } \\
\text { just say do it" } \\
\text { "We did not focus much on } \\
\text { multiple grade levels" } \\
\text { "I feel like we are told to use } \\
\text { them [standards] but never } \\
\text { told what a lot of them mean" }\end{array}$ \\
\hline Collaboration & Worked in groups & $\begin{array}{l}\text { "Most, if not all, class periods } \\
\text { heavily focused on working in } \\
\text { collaborative groups." } \\
\text { "Group tasks were } \\
\text { meaningful" } \\
\text { "A ton of collaborative groups } \\
\text { were used constantly" }\end{array}$ \\
\hline Problem solving & Challenging problems & $\begin{array}{l}\text { "Not only were the problems } \\
\text { challenging but they were very } \\
\text { informative" } \\
\text { "It was hard to get to } \\
\text { challenging problems with our } \\
\text { students" } \\
\text { "When teaching there were } \\
\text { not opportunities for } \\
\text { challenging problems because } \\
\text { we had no clue what the } \\
\text { students had already learned } \\
\text { so we had to start from } \\
\text { scratch" }\end{array}$ \\
\hline
\end{tabular}

